\title{
Neuropeptides and psychopathology
}

\author{
Citation for published version (APA):
}

Van Ree, J. M., Jolles, J., \& Verhoeven, W. M. A. (1990). Neuropeptides and psychopathology. In Neuropeptides: Basics and Perspectives (pp. 313-351). Elsevier.

Document status and date:

Published: 01/01/1990

Document Version:

Publisher's PDF, also known as Version of record

\section{Please check the document version of this publication:}

- A submitted manuscript is the version of the article upon submission and before peer-review. There can be important differences between the submitted version and the official published version of record.

People interested in the research are advised to contact the author for the final version of the publication, or visit the DOI to the publisher's website.

- The final author version and the galley proof are versions of the publication after peer review.

- The final published version features the final layout of the paper including the volume, issue and page numbers.

Link to publication

\footnotetext{
General rights rights.

- You may freely distribute the URL identifying the publication in the public portal. please follow below link for the End User Agreement:

www.umlib.nl/taverne-license

Take down policy

If you believe that this document breaches copyright please contact us at:

repository@maastrichtuniversity.nl

providing details and we will investigate your claim.
}

Copyright and moral rights for the publications made accessible in the public portal are retained by the authors and/or other copyright owners and it is a condition of accessing publications that users recognise and abide by the legal requirements associated with these

- Users may download and print one copy of any publication from the public portal for the purpose of private study or research.

- You may not further distribute the material or use it for any profit-making activity or commercial gain

If the publication is distributed under the terms of Article $25 \mathrm{fa}$ of the Dutch Copyright Act, indicated by the "Taverne" license above, 


\title{
IX. Neuropeptides and psychopathology
}

\author{
Jan M. Van Ree, Jelle Jolles, Wim M.A. Verhoeven
}

\section{Introduction}

The basis of the pharmacotherapy of psychopathological syndromes is the assumption that certain biochemical processes in the brain of patients suffering from these syndromes deviate from those of normal individuals. These biochemical processes may be implicated in the pathology of the syndrome or the symptoms accompanying the disease. Normalization of the altered function will then alleviate the symptomatology.

Most psychotherapeutic drugs are developed by performing animal studies. Three main strategies can be followed in this respect, the physiological, the pharmacological and the pathological approach. The physiological one investigates the biochemical processes and substances in the animal brain that are involved in certain behaviors and/or fundamental psychological processes. When such behaviors or psychological processes are disturbed in the patients, it is reasoned that these substances may be used to counteract these disturbances. Research in this field is also directed at developing procedures to induce similar disturbances in animals as observed in the patients (pathophysiology). The second approach, the pharmacological one, involves the characterization of specific chemical and/or behavioral actions in animals of drugs applied to relieve symptomatology in patients. This is followed by the search for similarities between the profile of a potential new drug and that of known drugs (pharmacological isomorphism). The pathological approach includes the specification of those processes in the patients' brain that deviate from those of normal individuals and subsequent induction of these disturbances in animals. Whether or not the various substances can alleviate the consequences of the disturbances can be tested. These three strategies have also been followed with respect to the prediction of a possible therapeutic action of neuropeptides in psychopathological syndromes. This review will focus mainly on neuropeptides related to adrenocorticotropic hormone (ACTH), vasopressin and $\gamma$-endorphin and includes both animal and human data. 


\section{ACTH neuropeptides}

Animal studies

Removal of the pituitary in animals results in a number of behavioral deficits. Among them is inferior learning performance as evidenced by a reduced ability of rats to acquire a conditional avoidance response (Applezweig and Baudry, 1955). A similar deficit has been reported for rats after removal of the anterior part of the pituitary (De Wied, 1964). Treatment with ACTH partly restored avoidance acquisition of these rats. Peptides structurally related to ACTH but practically devoid of corticotropic activity, such as ACTH-(4-10), mimicked the action of ACTH (De Wied, 1969). This substantiated the view that this action of $\mathrm{ACTH}$ is due to an extra-adrenal effect of the hormone and is elicited by a direct action on the brain. In intact rats, acquisition performance was facilitated and extinction was delayed by ACTH neuropeptides (for references see De Wied and Jolles, 1982). These peptides also facilitated passive avoidance behavior (Greven and De Wied, 1973). Other forms of aversive learning, such as conditioned taste aversion, can also be influenced by ACTH neuropeptides. In addition behavior rewarded by food and sexual contact is affected by the peptides (for references see De Wied and Jolles, 1982). Several hypotheses have been presented about the mechanism of action of ACTH neuropeptides, taking into account the above-mentioned effects on animal behavior, but also data obtained from electrophysiological and heart rate studies. These peptides may facilitate learning and memory retrieval, alter fear and enhance motivation, vigilance, (visual) attention and concentration (De Wied and Jolles, 1982). Most of the experiments done so far suggest that retrieval rather than storage of information is affected by ACTH neuropeptides. Although the animal studies with ACTH started with induction of pathology (removal of the pituitary), the implication of ACTH neuropeptides in, e.g., motivation and attention was based on the physiological approach type of experiments. The peptides may thus be used in patients with decreased motivation, attention, concentration, learning and memory retrieval.

Pathophysiological studies have also been ${ }_{n}$ performed in animals with respect to ACTH neuropeptides. The studies on social behavior may serve as an example. Modifications in the sequence ACTH-(4-9) have led to highly potent peptides (see Chapter VII). Thus, H-Met $\left(\mathrm{O}_{2}\right)$-Glu-His-Phe-D-Lys-Phe-OH (Org 2766) is about 1000 times more potent than ACTH-(4-10) in delaying extinction of pole-jumping avoidance behavior (Greven and De Wied, 1973). These changes have, however, also included new inherent activities in the 
peptide molecule (Fekete and De Wied, 1982). Animals that are confronted with a conspecific engage in bouts of intense social behavior. When animals that are adapted to low light are tested under high light conditions their social behaviors are diminished as compared to animals tested under low light conditions. This effect is facilitated by ACTH-(4-10), but counteracted by Org 2766 (File, 1981; Niesink and Van Ree, 1983, 1984a). Thus, under these conditions Org 2766 stimulates social contacts. On the other hand, the increase in social behaviors induced by short-term isolation is diminished by Org 2766 (Niesink and Van Ree, 1983). Thus, Org 2766 may "normalize" disturbances in social behaviors due to changes in the environment. This action of Org 2766 is antagonized by opioid antagonists, implicating endorphins in this peptide action (Niesink and Van Ree, 1983). Org 2766 may thus be recommended in patients with disturbed social behaviors.

With respect to the pathological approach, two lines of research can be mentioned. First, ACTH neuropeptides accelerate the morphological and functional recovery in rats with a crushed sciatic nerve (Verhaagen and Gispen, 1988). The peptide also protects against the neurotoxic effects induced by treatment with, e.g., acrylamide and cisplatin (see Chapter VI). Second, beneficial effects of ACTH neuropeptides have been reported after brain damage (Nyakas et al., 1985; Wolterink et al., 1989; Spruijt, unpublished data). For example, rats with lesions in the nucleus accumbens, induced by injecting the neurotoxic 6-hydroxydopamine, display motor impairment. The animals recover from this behavior deficit in about 3-4 weeks. Treatment with ACTH neuropeptides, including Org 2766, during the first week after the lesion accelerates this spontaneous recovery. These pathological studies may suggest a possible therapeutic effect of these peptides after damage of the peripheral nervous system (e.g., due to trauma, cancer therapy or diabetes) and the central nervous system (e.g., due to trauma, infection, operation or progressive degenerative diseases).

Summarizing, on the basis of animal research ACTH neuropeptides including Org 2766 may be useful in patients with impairments in attention, motivation, learning or memory retrieval, social behaviors, or damage of the peripheral and central nervous system. It should be kept in mind that the profile of action of Org 2766 may differ from that of ACTH-(4-10) in certain respects, which may have consequences for the clinical use of these peptides.

Human studies

The finding that ACTH-like peptides can influence attention and motivation in animals has stimulated similar studies in man. The majority of these 
human studies have been performed in the 1970s and early 1980s. Excellent reviews which date back to 1981 and 1982 already state that generally no consistent effect of ACTH-(4-10) and Org 2766 on memory task performance has been found (Pigache, 1982; Pigache and Rigter, 1981). These authors concluded that Org 2766 and ACTH-(4-10) do not have clear effects on memory processes and that those positive findings that have been published are most probably due to methodological short-comings (e.g., statistical methods that were not used correctly, and the use of wrong tests; Pigache and Rigter, 1981). This absence of significant effects on memory processes has been observed in healthy young subjects, in patients treated with electroconvulsant therapy, in children with minimal brain dysfunction and in alcoholics and other people showing signs of cognitive deficits (Tinklenberg and Thornton, 1983). Initial trials with both healthy subjects and patients have used either a single dose of the peptide ("acute" treatment) or a relatively short period of administration.

It is only in certain conditions that single doses of ACTH-(4-10) or Org 2766 appear to enhance human performance on behavioral tasks (for review see Born et al., 1986). For instance, Org 2766 has been found to enhance performance in certain tasks of visual perception and discrimination and in tasks which required sustained attention or vigilance during long and monotonous sessions (e.g., Beckwith and Sandman, 1982). Gaillard (1981) suggested that ACTH does not influence "selective attention", but "task-directed motivation". This specific motivation cannot be explained as a change in general motivation or activation, because the peptide did not affect the basal heart frequency. The studies in elderly people did not give the clear-cut effects that had been found in younger subjects (O'Hanlon in Pigache, 1982). The human vigilance studies are not of immediate clinical importance because the improvement in the individual subjects was too small. It has therefore been concluded that higher or repetitive dosage schedules might be more effective. However, the studies do provide relevant theoretical information. For instance, consensus has been reached on the hypothesis that the ACTH effects are not on intrinsic, information-containing memory functions per se, but instead on extrinsic memory-modulating processes or other factors that affect task performance, especially during prolonged testing sessions (Gaillard, 1981; Squire and Davis, 1981; Tinklenberg and Thornton, 1983).

(Sub)chronically administered Org 2766 (i.e., for more than 6 days) appears to have positive effects in elderly patients. Ferris and co-workers (1980) treated elderly subjects who had mild to moderate cognitive impairment but were living in the community. These people were not depressed or anxious. 
Consistent results were found with a rating instrument, in that there was a significant decrease in the "depression" score and an increase in self-rated "competence". Also the "anxiety" score was significantly decreased. A second study, with more severely impaired geriatric inpatients, used an observer rating scale to evaluate the drug effect: significant treatment effects were found with respect to "ward behavior" and "social behavior" (Braverman et al., 1980; see Pigache, 1982; Pigache and Rigter, 1981), Other double-blind studies reported significant effects with respect to "anxiety" and "social behavior" (see Pigache and Rigter, 1981). In yet another study in which the peptide effect was evaluated by a self-rating scale, no significant peptide effect was found (Branconnier and Cole, 1977; see Pigache, 1982; Pigache and Rigter, 1981).

The peptides have also been studied in demented patients. In one study with mildly to moderately demented patients positive effects were noticed (decreased SCAG scores, increased cognition, decreased somatic dysfunctions) (Kragh-Sørensen and Lolk, 1987). In two other studies with more severely demented patients no effects were observed (Martin et al., 1983; Soininen et al., 1985). No effect of chronic treatment with Org 2766 on the symptomatology of depressed patients was found (Frederiksen et al., 1985). An increase in gregarious and social behaviors has been noted in a study in which mentally retarded adults were given Org 2766 (Sandman et al., 1980). There was a lack of effect of Org 2766 given to hyperkinetic children (Butler and co-workers in Pigache and Rigter, 1981), but recently a beneficial effect of Org 2766 has been reported in autistic children (e.g., on play behavior) (Buitelaar et al., 1990).

All these findings suggest that Org 2766, especially if given repeatedly for a longer period of time, can affect human behavior in certain conditions. With respect to its mechanism of action, an action on extrinsic memory processes (Squire and Davis, 1981) is most probable, especially since the ascending fiber system, which is known to be involved in the behavioral effects of the ACTH peptides in animals (De Wied and Jolles, 1982), is also involved in mood and depression in man and in dementia.

\section{Vasopressin neuropeptides}

Animal studies

Research on the behavioral effects of vasopressin was initiated by the observation that removal of the posterior lobe of the pituitary, including the 
pars intermedia, did not interfere with acquisition of avoidance behavior, but resulted in a rapid extinction of the learned response (De Wied, 1965). Subsequent studies revealed that treatment with pitressin, a crude extract of posterior pituitary tissues, and also with vasopressin could restore the behavioral deficit (De Wied, 1965, 1969). Later, effects of vasopressin and related peptides have been demonstrated in intact rats as well. These and other studies have led to the notion that vasopressin neuropeptides are involved in memory processes (De Wied, 1984). Arguments in favor of the memory hypothesis are (1) a single injection with vasopressin neuropeptides induces a long-term effect that is still present after the administered peptide has disappeared from the body; (2) there appears to be a time-dependent effect; vasopressin neuropeptides are only fully active when administered in association with the behavior; (3) vasopressin neuropeptides can prevent and reverse experimentally induced retrograde amnesia. Vasopressin neuropeptides can facilitate both consolidation of information and retrieval of acquired information, as revealed in experiments using the passive avoidance procedure. Recently, it was shown that vasopressin can facilitate social recognition, one of the requirements of social cognition (Dantzer et al., 1987). Vasopressin in the body has been implicated in the mechanism underlying memory processes. In this connection studies have been performed in rats after removal of the posterior pituitary, in diabetes insipidus animals lacking the ability to synthesize vasopressin, and in rats after temporary bio-inactivation of vasopressin by injecting vasopressin antiserum.

Disrupting the circadian organization of rats by changing the day-night cycle resulted in an attenuated retrieval of recently acquired information as evidenced by studies using the active and passive avoidance procedures. The disturbance was related to the time given the animal to adapt to the new cycle; no disturbances were present after 5 days of adaptation. This behavior deficit could be restored by a single injection with vasopressin neuropeptides (Fekete et al., 1986). Detailed analysis of this phenomenon pointed to a disturbance in retrieval processes. Social interactions were not changed by disrupting the circadian organization. Thus, the results from animal experiments suggest that vasopressin neuropeptides might be useful in humans who are exposed to circadian disruption while travelling, or who switch from day to night work or vice versa.

A psychopathological model of addictive behavior is the self-administration of drugs in animals (Van Ree, 1979). Acquisition of heroin and cocaine self-administration was diminished by treatment with vasopressin neuropeptides (Van Ree and De Wied, 1977a; Van Ree et al., 1988). Vasopressin 
may be involved in this behavior, since administration of vasopressin antiserum into the cerebrospinal fluid resulted in an increase of heroin and cocaine intake (Van Ree and De Wied, 1977b; De Vry et al., 1988). It has been proposed that vasopressin neuropeptides decrease the reward elicited by the heroin or cocaine injection. That the peptide may modulate brain reward was supported by experiments showing that vasopressin neuropeptides decreased the response from electrical stimulation of the so-called brain pleasure centers (Dorsa and Van Ree, 1979). Recently, it was found that vasopressin neuropeptides also decreased acquisition of alcohol drinking in monkeys (Kornet et al., unpublished data). It seems worthwhile to study in detail the effects of vasopressin neuropeptides on human addictive behavior.

\section{Human studies}

Vasopressin and related peptides have been applied in humans in many studies involving volunteers and patients with various disorders including memory disturbances. Unfortunately, there are many differences among the studies with respect to the aspect(s) of memory affected, the type of patient, the severity of the defects and the methods used for treatment evaluation (Jolles, 1983, 1986, 1987; Van Ree et al., 1985). In addition, the studies differ with respect to the dose, route, frequency and duration of peptide administration and the experimental design used (open, blind, etc.). Furthermore, different vasopressin congeners have been used which differ with respect to the peripheral side effects: the mother hormone $\left[\mathrm{Lys}^{8}\right]$ vasopressin (LVP) has antidiuretic, vasopressor and behavioral effects; its congener desamino-[D$\operatorname{Arg}^{8}$ ]vasopressin (DDAVP) has antidiuretic and behavioral effects. For a critical and more elaborate discussion of the human vasopressin studies, see Jolles, 1983, 1986, 1987; Van Ree et al., 1985; Messing and Sparber, 1984; Sahgal, 1984. The following paragraphs describe the human studies performed with vasopressin congeners for the particular patient groups that have been studied to date.

\section{Summary of the clinical trials}

Head trauma. The first clinical experiments concerning the anti-amnesic effects of vasopressin-like peptides were open or semi-controlled trials with LVP administered by nasal spray. These trials were generally positive as to treatment effects of the peptide (e.g., Oliveros et al., 1978; Timsit-Berthier et al., 1980; Verhoeven et al., 1980 in Jolles, 1987) and concerned mildly to 
moderately traumatized patients. No treatment effects were seen in patients with more serious head injuries. For instance, no effect was seen after treatment of such patients with low or high doses of DDAVP, desglycinamide vasopressin (DGAVP) or LVP (e.g., Jenkins et al., 1981; Fewtrell et al., 1982).

Amnesic syndrome associated with chronic alcoholism. Treatment effects of LVP in alcoholic patients have been published in several single-case studies and control studies (e.g., Oliveros et al., 1978; Peabody et al., 1985) but other authors did not find effects with DGAVP or DDAVP (e.g., Tinklenberg et al., 1982). Other negative outcomes with LVP, DDAVP or DGAVP were reported in severe chronic alcoholics (Korsakoff's syndrome; e.g., Jenkins et al., 1982; Jennekens-Schinkel et al., 1985). The notion that a serious amnesic syndrome induced by alcohol does not benefit from treatment with vasopressin-like peptides is strengthened by the findings of Láczi et al. (1983a,b). These investigators found positive treatment effects in mild but not severe alcoholic subjects.

Aging and senile dementia. LVP effects were described in a controlled study in hospitalized elderly patients (Legros et al., 1978) and in senile demented subjects (Delwaide et al., 1980). Likewise, positive findings were made in patients suffering from primary progressive dementia receiving a single dose of DGAVP (Weingartner et al., 1981b) or 7 days of LVP (Ferris, 1983). However, Durso et al. (1982) found no effects of LVP on tests of memory, learning and visual perception. As there was a positive effect on the reaction time test, these investigators concluded that vasopressin might have a non-specific activating effect. Similar suggestions were made by Tinklenberg et al. (1982). Generally more severely demented multi-infarct patients and Alzheimer patients did not benefit from peptide treatment (Jenkins et al., 1982; Jennekens-Schinkel et al., 1985).

Depression and schizophrenia. Several investigators have claimed that the anti-amnesic action of vasopressin-like peptides is related to an antidepressant effect. In studies in which patients with endogenous depression and cognitive disorders were treated with DDAVP three out of four patients manifested a significant improvement in the level of cognitive functioning (Weingartner et al., 1981a). Similar improvements in mildly to moderately depressed subjects were reported by others after LVP (Vranckx et al. in Legros and Lancranjan, 1984). No effects were found in severely depressed subjects (e.g., Lerer in Legros and Lancranjan, 1984). 
Interestingly, vasopressin effects have also been found in schizophrenic patients, especially on those symptoms that are not influenced by neuroleptics. such as emotional withdrawal, anergia and blunted affect. The first indications were already found in 1937 in chronic schizophrenics treated intramuscularly with pitressin (Forisz, 1952 in Jolles, 1987). Likewise, Korsgaard et al. (1981) noted a decrease in thought disorder, accompanied by an increase in energy and activity in $40 \%$ of the treated patients, whereas others reported that LVP may have a beneficial effect on emotional withdrawal and blunted affect (see Jolles, 1986, 1987 for a more elaborate description).

Other patients. Memory processes are reported to be improved in diabetes insipidus patients, in open studies with DDAVP and in double-blind studies with LVP, DDAVP or DGAVP applied intranasally or intramuscularly (see Jolles, 1987 for a more elaborate description). Likewise, treatment effects of vasopressin are reported in patients suffering from deep brain lesions of varying etiology, such as those caused by herpes simplex encephalitis, hypothalamic disorders, brain surgery and Lesch-Nyhan disease (see Jolles, 1987). No effect was found in cases of brain hypoxia and Down syndrome (e.g., Fewtrell et al., 1982). Specific effects of DDAVP on memory retrieval were reported in a study of children with attention and learning disorders (Eisenberg et al., 1985). Finally, DGAVP appears to improve the detoxification of heroin addicts (Fraenkel et al., 1983; Van Beek-Verbeek et al., 1983). The addicts were sublingually treated with DGAVP or placebo during the initial phase of methadone detoxification in an outpatient clinic. There were five variables of treatment evaluation, namely the success of detoxification, the attendance at the clinic, the presence of morphine - a metabolite of heroin and cocaine in the daily urine samples and the judgement of the medical attendant. DGAVP treatment resulted in a significant improvement in all variables as compared to placebo treatment.

Healthy volunteers. Volunteers without memory deficits have also been found to benefit from treatment with LVP or DDAVP (Weingartner et al., 1981a; Láczi et al., 1982) or DGAVP (Láczi et al., 1983a). These treatment effects were determined in tests which are thought to measure aspects of memory. Negative effects were reported by Fehm-Wolfsdorf et al. (1985) with LVP and by Jenkins et al. (1982) with DDAVP. Beckwith and co-workers, however, showed in a series of experiments with information processing tasks that acute administration of DDAVP enhanced learning performance on a concept-shifting task. They concluded that the peptide influences memory via an action on 
attentional processes (e.g., Beckwith et al., 1983, 1984). Peptide effects on similar information processing tasks as those used by Beckwith et al. were reported by Nebes et al. (1984): their data again suggest that the peptide has a specific influence on particular aspects of memory and not on others.

Evaluation of the human studies

Pharmacological parameters. The human studies with vasopressin-like peptides differ in many aspects, including the type of peptide fragment used. Four vasopressin congeners are used: VP, LVP, DDAVP, DGAVP. As LVP, VP and DDAVP have peripheral side effects (antidiuretic/cardiovascular and cardiovascular respectively) a crucial point concerns the perception by patients of changes taking place in their bodies. Consequently DGAVP seems to be the peptide of choice in order to exclude these peripheral effects.

An important point concerns the route by which the peptide enters to the brain. Vasopressin-like peptides have been administered by the following routes: intranasally, intramuscularly, sublingually, orally. Most investigators presently use the intranasal route particularly because the intramuscular route has practical disadvantages. Unfortunately, there is a paucity of reports on the accessibility of the CNS for the peptides (Ang and Jenkins, 1982; Riekkinen et al., 1987).

With respect to the duration of administration some reports state that a single administration of VP or DDAVP in patients can induce a measurable anti-amnesic effect and that these effects are still present after $48 \mathrm{~h}$. Hence the parallel with animal experiments in which acute effects of the peptide have been reported. However, quite a few reports state that the clinical impression exists that the effects develop in time. It may be the case that the effects seen after a single administration are dependent on the moment of assessment, as has been found in animal experiments (De Wied, 1984). In addition, the relatively clear-cut effects - although small - seen after a single administration in volunteers may have to do with the homogeneity of the subject groups used.

Neuropsychological parameters. Memory complaints accompany many diseases. Accordingly, it is not to be expected that one drug will have a beneficial effect in all neural and psychiatric disorders in which memory processes are affected. Nevertheless, many clinical studies with vasopressin have been performed under this false premise, as can be seen in the preceding sections, 
which bear witness to the fact that patient groups suffering from such various disorders as brain trauma, alcoholism, dementia and schizophrenia have been used in the clinical trials. It appears not to be known that it is necessary to discriminate true memory disorders from those that are secondary to another disorder. For instance, memory complaints can result from general slowness or from a planning disorder. Alternatively, attentional deficits, language deficits or concentration deficits can be translated as memory complaints.

Finally, motivation processes and the state of activation or arousal of the organism can also play a role in a deficient memory performance. This has also been found in animal experiments (De Wied and Jolles, 1982; Jolles, 1983). There is evidence that the different aspects of memory c.q. memory processes depend upon different cerebral substrates. Thus, posterior neocortical structures subserve another aspect of memory than frontal structures, the limbic system or the ascending fiber system (see Jolles, 1986, 1987 for more elaborate discussion). Interestingly, according to Squire and Davis (1981) many memory-active drugs act primarily or exclusively on the ascending fiber system which underlies the extrinsic memory system. When evaluating neuropeptide effects on patients and volunteers it is therefore important to specify the action of the drugs in terms of different aspects of memory and cognition. The best studies in this respect are those in which measures have been used that depend on information processing paradigms (e.g., the studies of Beckwith et al., 1983, 1984; Gaillard, 1981; Nebes et al., 1984).

With respect to the nature of the patient population, it appears that relatively more clear-cut peptide effects were found in persons suffering from relatively mild cognitive complaints without serious structural change in the brain. This notion evolved in the vasopressin studies of trauma, alcoholic, aging and depressed subjects. It appears that structural damage in the brain prevents the development of the peptide effect. Alternatively, in patients suffering from more than one cognitive disorder, a possibly beneficial effect of the peptide may become submerged in the other psychopathology. Again, it is important to recognize that it is not to be expected that vasopressin affects all cognitive processes as the animal experiments are suggestive of a specific action of these peptides (see De Wied and Jolles, 1982; De Wied 1984).

The interpretations put forward in the human studies are quite diverse and range from "general" effects on general arousal to "specific" effects on particular aspects of information processing/memory processes. Accordingly, the data gathered in human psychopharmacological research are in line with the suggestions made by De Wied (e.g., De Wied, 1984). More research is needed to draw more definite conclusions as to the cognitive functions 
involved, but consensus exists in the sense that there is an effect of vasopressin-like peptides on behavior in man.

\section{A multiple clinical trial}

The preceding paragraphs show that it is not to be expected that treatment with vasopressin peptides should be equally effective in all types of cognitive impairment. Of importance was the fact that most studies in which the peptide was ineffective were performed in patients with a complex pattern of neuropsychological deficits or other symptoms suggesting profound brain damage. This is not surprising as a lack of effect of exogenously administered vasopressin peptides was also seen in rodents after lesioning of particular diencephalic areas (Van Wimersma Greidanus et al., 1983). It was thus hypothesized, first, that the subjects of choice for vasopressin peptides would be patients presenting cognitive dysfunctions resulting from brain trauma, depression, senescent forgetfulness or early stages in dementia and, second, that patients should be characterized neuropsychologically, to assess specific influences on different aspects of memory. In addition, the use of more specific and more sensitive methods of treatment evaluation should make it more probable that treatment effects are found. Because of the findings in volunteers, information processing tasks should prove of value in this respect (e.g., Nebes et al., 1984). Finally, the nature and amount of the pharmacologically active principle was deemed to be of importance. This is because the amount of vasopressin that can be used in humans is limited due to the peripheral effects alluded to in preceding paragraphs.

The studies by Hijman et al. and Jolles et al. (unpublished data) describe a series of five consecutive clinical trials in which the effect of DGAVP was tested against placebo. The patients used for the studies were carefully selected by neuropsychological assessment procedures resulting in more homogeneous populations of patients with cognitive deficits. The variables "dose", "route of administration", "treatment schedule", "diagnostic group" and "severity of deficits" were varied from experiment to experiment in order to find optimal conditions for the expression of the peptide effect and thus to answer the decisive question whether or not DGAVP had an effect on cognitive/memory functions in patients and, if so, whether there is a specific effect. Recently developed information processing tasks in parallel versions were used throughout the studies. The results indicate significant DGAVP effects on wordlist learning in mild brain trauma patients, suggesting an improved learning performance and memory retrieval after peptide treatment in these 
patients. More severely brain-traumatized patients did not respond to peptide treatment. Some DGAVP effects on speed of memory search were observed in patients with age-associated memory deficits. With respect to the experimental variables which were varied from trial to trial in order to find optimal conditions for the expression of the peptide effect, the major relevant factor appeared to be the factor "diagnostic group" because clear-cut peptide effects were found in light brain trauma patients. Concerning the variables "route of administration" and "dose" it has not been clearly established in the present series of trials whether the intranasal route is superior to the oral route: however, the fact that some patients subjectively reacted to oral treatment gives an indication that oral treatment might be effective.

With respect to the dose: $1 \mathrm{mg}$ DGAVP was most probably not too high (see Jolles, 1987) and it was recommended to carry out dose finding studies in which higher doses than $1 \mathrm{mg}$ are used. In addition, the treatment period should have a minimum duration of several weeks, preferably months. There were indications that the treatment effect developed in time and that there was even an after-effect which was present after termination of DGAVP administration.

Interestingly, when the data obtained in 75 subjects treated with DGAVP were analyzed according to single-case statistics significant effects were found in favor of DGAVP treatment: two experienced judges had to predict (i.e., judge) on each individual case whether the patient had belonged to treatment group A (sequence DGAVP-placebo in a double-blind crossover design) or treatment group B (sequence placebo-DGAVP). There was a significant correspondence between prediction and actual group membership at $P<0.003$; importantly, two out of three wrongly predicted patients had experienced a late after-effect of peptide treatment in the first period. Of great relevance is the finding that 18 of 28 predicted patients belonged to the subgroup of mild brain trauma patients. Taken together these data were taken as conclusive evidence in favor of a DGAVP effect in light brain trauma patients who are characterized by a post-traumatic syndrome.

\section{$\gamma$-Type endorphins}

Animal studies

The idea that $\gamma$-type endorphins may have antipsychotic properties was initially generated by principles of pharmacological isomorphism (De Wied et 
al., 1978). $\gamma$-Endorphin and the non-opioid peptide (des-Tyr $\left.{ }^{1}\right)-\gamma$-endorphin (DT $\gamma$ E) facilitated the extinction of pole-jumping avoidance behavior and attenuated passive avoidance behavior in rats. Similar effects can be elicited by treatment with neuroleptics, e.g., haloperidol. Also in other tests similarities between the action of DT $\gamma E$ and neuroleptics have been reported. These tests include induction of grasping response, attenuation of brain stimulation reward and acquisition of heroin self-administration and antagonism of hypomotility, induced by low doses of apomorphine (see Van Ree and De Wied, 1982; Van Ree et al., 1987). Differences between the effects of DT $\gamma \mathrm{E}$ and neuroleptics were present as well. The sedation induced by DT $\gamma \mathrm{E}$ was less pronounced than with haloperidol and the peptide hardly displaced dopamine agonists and antagonists from their brain binding sites, as haloperidol does (De Wied et al., 1978; Van Ree et al., 1978). It has been proposed that tests in which classical neuroleptics (e.g., haloperidol), atypical neuroleptics (e.g., sulpiride) and $\gamma$-type endorphins are active may be used to predict the antipsychotic activity of substances (Van Ree and De Wied, 1982). These tests include conditioned avoidance behavior, grasping responses and inhibition of apomorphine-induced hypomotility. It should be kept in mind, however, that this suggestion is based on empirical observation and thus liable to change. The proposed tests were used to perform structure-activity relationship studies. It appeared that desenkephalin- $\gamma$-endorphin $(\mathrm{DE} \gamma \mathrm{E})$ is the shortest peptide fragment that was active in all these tests when administered subcutaneously (De Wied et al., 1980; Van Ree et al., 1982a). $\alpha$-Endorphin, a peptide with only one amino acid less than $\gamma$-endorphin, induced an opposite effect in most tests in which $\gamma$-type endorphins are active (De Wied, 1978; Van Ree et al., 1987). The effect of $\alpha$-endorphin in certain respects resembles the effects induced by the psychostimulant drug amphetamine. This drug can induce or increase psychotic symptomatology in volunteers or patients respectively. The neuroleptic-like action of $\gamma$-type endorphins and the amphetamine-like effects of $\alpha$-type endorphins led to the postulate that the balance between $\alpha$ - and $\gamma$-type endorphins may be pertinent for a role of these peptides in the etiology of schizophrenia and that $\gamma$-type endorphins may have antipsychotic activity (De Wied, 1978).

Although the ultimate proof that a certain substance has antipsychotic properties can only be achieved in humans by treating psychotic patients, research in experimental animals may support the antipsychotic effects of that substance and can contribute to the elucidation of its mode of antipsychotic action. Concerning the pathology in the brain of schizophrenics, most theories have concentrated on dopamine. The dopamine hypothesis in its simple form 
states that dopaminergic hyperactivity in some brain systems plays a key role in the pathogenesis of schizophrenia. Although there is at present no convincing evidence for the dopamine hypothesis as far as biochemical evaluations of schizophrenic patients are concerned, it is reasonable to assume that dopamine is involved in this disorder, at least as a mediator in brain pathways implicated in some psychotic symptoms. Several distinct dopaminergic systems are present in the brain, e.g., the nigrostriatal, the mesolimbic, the mesocortical, the tuberoinfundibular and the intradiencephalic systems. The mesolimbic and mesocortical dopamine systems with cell bodies in the ventral tegmental area and terminals in several areas of the limbic forebrain (e.g., nucleus accumbens and amygdala) and in cortical regions (e.g., prefrontal cortex and pyriform cortex) have been specially implicated in schizophrenia (Stevens, 1979). The nuclei of the limbic forebrain have been associated with perceptual, cognitive, attentional and affective processes, which are commonly disturbed in schizophrenics.

In a series of experiments the acute interaction between $\gamma$-type endorphins and the behavioral effects of dopaminergic agonists was studied in detail (for references see Van Ree et al., 1987, 1989). These interaction studies were initially performed following systemic treatment. Subsequently injections were made into terminal areas of the different dopaminergic systems. Injection of high doses of the dopamine agonist apomorphine into the nucleus caudatus, the terminal area of the nigrostriatal dopaminergic pathways, elicited a stereotyped sniffing response that could be blocked by local treatment with haloperidol and sulpiride but not with $\gamma$-type endorphins. A similar injection of apomorphine into the nucleus accumbens induced hypermotility, which could be blocked with haloperidol and sulpiride, but not with the non-opioid $\gamma$-type endorphins. Low doses of apomorphine injected into this area resulted in a hypomotility response, which could be antagonized by local treatment with haloperidol, sulpiride and $\gamma$-type endorphins. These low doses of apomorphine presumably activate presynaptically located dopaminergic receptors. Thus, the interaction between $\gamma$-type endorphin and dopamine in the nucleus accumbens may be at the presynaptic level. Injection of low or high doses of apomorphine into the pyriform cortex resulted in a stereotyped sniffing response, which differed qualitatively from that induced by injection of the substance into the nucleus caudatus. This response was potently blocked by local pretreatment with haloperidol, sulpiride and $\mathrm{DE}_{\gamma} \mathrm{E}\left(\mathrm{ED}_{50}<1 \mathrm{pg}\right)$. These data indicate that $\gamma$-type endorphins can, like other antipsychotic substances (e.g., haloperidol and sulpiride), interact with dopaminergic responses elicited in terminal areas of the mesolimbic and mesocortical dopaminergic systems. Thus, this interac- 
tion may be related to the antipsychotic action of these compounds. The lack of an interaction between apomorphine and $\gamma$-type endorphins when injected into the nucleus caudatus suggests that these peptides may be devoid of extrapyramidal side effects.

The opioid peptide $\gamma$-endorphin mimicked the effects of the non-opioid $\gamma$-type endorphins in antagonizing the hypomotility elicited by low doses of apomorphine. This interaction is presumably at the presynaptic level of dopaminergic nerves in the nucleus accumbens. In contrast to the non-opioid $\gamma$-type endorphins, $\gamma$-endorphin may also interfere with mechanisms at the postsynaptic level of these neurons. The hypermotility induced by intra-accumbens injection with apomorphine and amphetamine can be blocked by local pretreatment with $\gamma$-endorphin (Van Ree et al., 1984). This effect of $\gamma$-endorphin is antagonized by local treatment with the opioid antagonist naloxone, indicating the involvement of opioid receptor systems. Other opioid peptides, like $\alpha$ - and $\beta$-endorphin and enkephalins, did not mimic the effect of $\gamma$-endorphin (Van Ree and Gaffori, 1983). Thus, uniquely, $\gamma$-endorphin has an action that is both opioid- and neuroleptic-like. Since $\gamma$-endorphin interacts both at the pre- and at the postsynaptic level of dopaminergic neurons at least in the nucleus accumbens, the profile of this peptide in this respect may resemble that of classical neuroleptics. Thus, it seems worthwhile to look in detail at the action of $\gamma$-endorphin in psychotic patients as compared to that of the non-opioid $\gamma$-type endorphins.

Chronic treatment of rats with $\gamma$-type endorphins makes the animals more sensitive to the effect of low doses of apomorphine (see Van Ree et al., 1987). This may suggest that such treatment leads to supersensitivity of the dopamine receptor system activated by low doses of apomorphine. These receptor systems are presumably located presynaptically and may be involved in regulation of dopamine release among others. Consistently, chronic treatment with $\gamma$-type endorphins decreased the release of dopamine in the nucleus accumbens as determined in experiments using in vitro accumbens tissue and using the dialysis method to assay the dopamine release in vivo (Radhakishun et al., 1990). The diminished release of dopamine after chronic treatment with $\gamma$-type endorphin is in line with the dopamine hypothesis of schizophrenia and may be the biochemical basis of the antipsychotic action of these peptides.

A series of studies have been performed in which the activity of the $\gamma$-type endorphins was chronically blocked. It was reasoned that such a decreased activity may resemble the purported biochemical disturbance in the schizophrenic brain, at least with respect to $\gamma$-type endorphins. The activity of $\gamma$-type endorphins was blocked in two ways: (1) neutralizing the bioavailability 
of $\gamma$-type endorphins by repeatedly injecting $\gamma$-endorphin antiserum into the nucleus accumbens and (2) blocking the receptors of $\gamma$-type endorphins by chronic treatment with anti-idiotyped antibodies. Both treatments resulted in an attenuation of the apomorphine-induced hypomotility (unpublished data) and in increased locomotion especially when rats were repeatedly tested (see Van Ree et al., 1987 and unpublished data). The opposite effect of chronic treatment with $\gamma$-endorphin and with $\gamma$-endorphin antiserum with respect to apomorphine-induced hypoactivity suggests that $\gamma$-type endorphins may modulate the setpoint for feedback regulation in neurons equipped with $\gamma$-type endorphin-sensitive dopamine receptor systems. Since rats chronically treated with $\gamma$-endorphin antiserum into the nucleus accumbens may serve as a model for schizophrenic psychoses, such treated rats were studied in detail. It was concluded that chronic treatment with antiserum may lead to disturbances in the interpretation and integration following perception of sensory stimuli, resulting in diminished habituation and/or adaptation, impaired cognitive capacities, deficits in social behavior and, under certain conditions, enhanced responses to stress-inducing stimuli (Van Ree et al., 1986). Such symptoms are not uncommon in schizophrenic patients. Thus, these rats might indeed serve as a model for schizophrenic psychoses, at least with respect to symptomatology, but more studies are needed to substantiate this view.

\section{Human studies}

To evaluate the proposed antipsychotic activity of $\gamma$-type endorphins we have performed a number of clinical trials in which DT $\gamma E$ or DE $\gamma E$ was given to patients suffering from different types of schizophrenia and schizo-affective psychoses (Verhoeven et al., 1979, 1981b, 1982, 1984b, 1986b and unpublished data of four patients). All patients showed clear positive psychotic symptoms and most of them were relatively resistant to conventional neuroleptic medication and exacerbations had occurred despite neuroleptic maintenance therapy. The outline of these studies is summarized in Table 1. The diagnosis was based upon the data of a complete Present State Examination (PSE) interview, including analysis according to the CATEGO computer program, and the course of disease.

Schizophrenic patients were classified subsequently according to the DSMIII criteria and those with schizo-affective psychoses according to the Research Diagnostic Criteria. In contrast to these criteria, the qualification "residual type of schizophrenia" was restricted to patients who had been hospitalized without interruption for at least 5 years while showing predomi- 
TABLE 1 Clinical trials with $\gamma$-type endorphins in schizophrenia (Utrecht/Netherlands)

\begin{tabular}{|c|c|c|c|c|c|}
\hline Study & Peptide & $\begin{array}{l}\text { Num- } \\
\text { ber of } \\
\text { patients }\end{array}$ & Design & $\begin{array}{l}\text { Neuroleptic } \\
\text { medication }\end{array}$ & $\begin{array}{l}\text { Peptide } \\
\text { treatment }\end{array}$ \\
\hline 1 & $\mathrm{DT} \gamma \mathrm{E}$ & 6 & open & $\begin{array}{l}\text { discontinued } \\
\text { I week before } \\
\text { trial }\end{array}$ & $\begin{array}{l}8-14 \text { days; } 1 \mathrm{mg} \\
\text { i.m. daily }\end{array}$ \\
\hline 2 & $\mathrm{DT}_{\gamma} \mathrm{E}$ & $8^{a}$ & $\begin{array}{l}\text { double-blind } \\
\text { cross-over }\end{array}$ & maintained & 8 days; 1 mg i.m. \\
\hline 3 & $\mathrm{DT} \gamma \mathrm{E}$ & 10 & $\begin{array}{l}\text { double-blind } \\
\text { cross-over }\end{array}$ & $\begin{array}{l}\text { discontinued } \\
>3 \text { weeks be- } \\
\text { fore trial }\end{array}$ & $\begin{array}{l}10 \text { days; } 1 \mathrm{mg} \text { i.m. } \\
\text { daily }\end{array}$ \\
\hline 4 & $\mathrm{DT} \gamma \mathrm{E}$ & $20^{b}$ & double-blind & discontinued & $\begin{array}{l}10 \text { days; } 1 \mathrm{mg} \text { i.m. } \\
\text { daily }\end{array}$ \\
\hline 1 & $\mathrm{DE} \gamma \mathrm{E}$ & 4 & single-blind & maintained & $\begin{array}{c}10 \text { days; } 1 \text { or } 10 \\
\text { mg i.m. daily }\end{array}$ \\
\hline 2 & $\mathrm{DE}_{\gamma} \mathrm{E}$ & 19 & $\begin{array}{l}\text { double-blind } \\
\text { placebo- } \\
\text { controlled }\end{array}$ & maintained & $\begin{array}{l}10 \text { days; } 3 \mathrm{mg} \text { i.m. } \\
\text { daily: } \mathrm{n}=13 \\
\text { placebo only: } \\
\mathrm{n}=6\end{array}$ \\
\hline 3 & $\mathrm{DE} \gamma \mathrm{E}$ & $8^{c}$ & $\begin{array}{l}\text { double-blind } \\
\text { cross-over }\end{array}$ & maintained & $\begin{array}{l}10 \text { days; } 3 \mathrm{mg} \text { i.m. } \\
\text { daily }\end{array}$ \\
\hline 4 & $\begin{array}{l}\mathrm{DE} \gamma \mathrm{E} / \\
\text { ceruletide }\end{array}$ & 44 & $\begin{array}{l}\text { double-blind } \\
\text { placebo- } \\
\text { controlled }\end{array}$ & maintained & $\begin{array}{l}21 \text { days; } 3 \text { mg i.m., } \\
7 \times \text { (ceruletide: } \\
n=15 ; \text { placebo: } \\
n=14)\end{array}$ \\
\hline 5 & $\mathrm{DE} \gamma \mathrm{E}$ & $20^{d}$ & $\begin{array}{l}\text { double-blind } \\
\text { cross-over }\end{array}$ & $\begin{array}{l}\text { never treated or } \\
\text { discontinued } \\
>6 \text { weeks } \\
\text { before trial }\end{array}$ & $\begin{array}{l}10 \text { days; } 3 \mathrm{mg} \text { i.m. } \\
\text { daily }\end{array}$ \\
\hline
\end{tabular}

ane patient was also included in study 1.

b Including two additional patients.

c Patients treated outside official protocols.

d Publication in preparation.

nantly negative symptoms together with positive psychotic symptoms, which had largely stabilized. The term "chronic" was used when the duration of the patient's last psychotic episode was 1 year or more. Evaluation of the psychotic symptoms was performed using among others the Brief Psychiatric Rating Scale (BPRS), including the five subscales. Response to treatment was defined a decrease of more than $20 \%$ of the baseline BPRS scores while a reduction of at least $50 \%$ was considered a clinically relevant improvement. 
In our studies, 43 patients were treated with $\mathrm{DT} \gamma \mathrm{E}, 60$ patients with $\mathrm{DE} \gamma \mathrm{E}$, and 20 patients with placebo only. Of the placebo-treated patients, three showed a slight response while the other 17 did not respond. In 49 of the patients treated with peptides (DT $\gamma \mathrm{E}: \mathrm{n}=22 ; \mathrm{DE} \gamma \mathrm{E}: \mathrm{n}=27$ ) a clinically relevant improvement was found, while some of them remained free of psychotic symptoms for at least 6 months after one or two consecutive treatment periods. This long-lasting beneficial effect was associated with some signs of improvement in social functioning, a lower dosage of neuroleptics and an extension of the interval between the psychotic periods (Van Ree et al., 1982b). Among the remaining 54 patients, a slight response was observed in 32 (DT $\gamma \mathrm{E}: \mathrm{n}=11 ; \mathrm{DE} \gamma \mathrm{E}: \mathrm{n}=21$ ) while 22 did not respond at all. In none of the patients were side effects, particularly of extrapyramidal origin, observed. Generally, the antipsychotic effect started after 3-7 days of active treatment and included both positive and negative symptoms. No obvious differences between the antipsychotic effects of $\mathrm{DT} \gamma \mathrm{E}$ and $\mathrm{DE} \gamma \mathrm{E}$ were observed.

Others have also investigated the effects of $\gamma$-type endorphins in schizophrenia. In 10 trials, five open and five controlled, including a total of 93 patients, a response to treatment was found in 24 subjects (for references see Verhoeven and Den Boer, 1988). This less favorable outcome may be related among others to the characteristics of the patients selected, in that it appeared from our data that patients suffering from chronic or residual type of schizophrenia or treated with relatively high doses of neuroleptics or presenting with severe negative psychotic symptoms seem to be less sensitive to treatment with $\gamma$-type endorphins. Recently two additional clinical studies with $\mathrm{DE} \gamma \mathrm{E}$ in schizophrenia have been reported of which the results are more or less comparable to ours. Kissling et al. (1986) treated 30 acute schizophrenic inpatients for 4 weeks with either $\mathrm{DE} \gamma \mathrm{E}$ or haloperidol, using a double-blind design. After a wash-out period, the patients received $3 \mathrm{mg}$ $\mathrm{DE} \gamma \mathrm{E}$ once daily as intramuscular injections or $10 \mathrm{mg}$ haloperidol as oral medication. No additional neuroleptic treatment was permitted. After 14 days of treatment, the mean improvement in both treatment groups was approximately the same in that no significant difference could be found on the different rating instruments. Three subjects in the $D E \gamma E$ group and four in the haloperidol group showed a 50\% decrease on the BPRS ratings. These results demonstrate that $D_{E} \mathrm{E}$ and haloperidol are equipotent with respect to their antipsychotic efficacy. In the study of Azorin et al. (1986), 93 schizophrenic patients with an acute exacerbation were randomly allocated to either 1,3 or $10 \mathrm{mg} D E \gamma E$ intramuscularly per day or placebo. Treatment was given for 4 weeks. Sixty-seven patients completed the trial. In this study baseline neuro- 
leptic medication was continued and unchanged. The results indicate that in the group of patients receiving $10 \mathrm{mg} \mathrm{DE} \gamma \mathrm{E}$ psychotic symptomatology had decreased significantly after 4 weeks. Azorin and coworkers concluded that $\mathrm{DE} \gamma \mathrm{E}$, in a dose of $10 \mathrm{mg}$ intramuscularly, exhibits antipsychotic effects without producing any noticeable adverse reactions.

The clinical results so far available demonstrate that $\gamma$-type endorphins induce antipsychotic effects in a number of schizophrenic patients. Since the response to peptide treatment varied from no response at all to complete remission of psychotic symptomatology, it was analyzed which factors could have influenced the responsiveness of the patients to treatment (see Van Ree et al., 1986; Verhoeven et al., 1986a). The following factors were included in these analyses: syndromal and diagnostic features, genetic aspects, positive and negative psychotic symptoms, duration of disease, duration of last psychotic episode and duration and dosage of previous neuroleptic treatment. The results of these analyses suggest that at least two main factors may be involved in the degree of responsiveness of the patients to treatment with $\gamma$-type endorphins. First, the intensity of pre-existing negative psychotic symptoms. Using the baseline BPRS item scores of each individual subject, it was found that the intensity of negative psychotic symptoms, particularly blunted affect, negatively influenced the degree of responsiveness to peptide treatment. It appeared that in the group of patients with a response of less than 50\%, negative psychotic symptoms (emotional withdrawal, motor retardation and blunted affect) are significantly more severe than in the group of patients with a clinically relevant improvement (response $<50 \%$ ). An approximately similar picture emerged from the baseline PSE syndrome profiles and subscores showing that symptoms which are included in the Slowness, Catatonic and Residual Syndromes and the BSO subscore are significantly more present and severe respectively in patients without a clinically relevant reduction of psychotic symptoms (response $<50 \%$ ). These data, acquired by analyses of BPRS as well as PSE data, suggest that a relatively high intensity of pre-existing negative symptoms may decrease the susceptibility of schizophrenic patients to treatment with $\gamma$-type endorphins. Interestingly, in patients who responded to peptide treatment a reduction of both positive and negative psychotic symptoms was observed.

Secondly, the occurrence of antigens belonging to the human leukocyte antigen (HLA) system. To this end, 64 of the patients treated with $\gamma$-type endorphins were typed for the HLA-A, $-\mathrm{B},-\mathrm{C}$ and $-\mathrm{DR}$ antigens, including a total of 42 antigens. It appeared that the incidence of HLA-B15, -Bw22 and -B13 was increased in the group of patients with a clinically relevant improve- 
ment as compared to the other group, suggesting that genetic factors coded for within the HLA region may be associated with the response of patients to treatment with $\gamma$-type endorphins (De Jongh et al., 1982; Van Ree et al., 1986). Subsequently, it was tested whether HLA class I antigens are involved in the binding of $\gamma$-type endorphins to their receptors. These in vitro experiments revealed that $\mathrm{DT} \gamma \mathrm{E}$ preferentially inhibited the binding of antibody sera against HLA-B15, -Bw22 and -B13 to lymphocytes, while the binding of antibody sera against other HLA-A or -B antigens was less or not affected by the peptides (Claas et al., 1988; Van Ree et al., 1986). Interestingly, a significant correlation was found between the degree of in vitro inhibition of the binding by $\mathrm{DT} \gamma \mathrm{E}$ and the relative risk of becoming a responder to treatment with $\gamma$-type endorphins among the individual HLA antigens, suggesting a functional relationship between these two phenomena. These results indicate that certain HLA antigens may function as or interfere with binding sites for $\mathrm{DT} \gamma \mathrm{E}$ possibly present at lymphocytes and support the idea that genetic and/or immunological factors are implicated in schizophrenia and in the underlying mechanisms of $\gamma$-type endorphin action.

In addition, the influence of $\mathrm{DT} \gamma \mathrm{E}$ on various biochemical parameters has been studied in humans. No consistent influence of the peptide on cerebrospinal fluid levels of homovanillic acid (HVA), 3-methoxy-4-hydroxyphenylglycol (MHPG) and 5-hydroxyindoleacetic acid (5-HIAA) was observed (Verhoeven et al., 1981b, 1984b). No changes were found either in the daily pattern of plasma levels of growth hormone and cortisol during DT $\gamma \mathrm{E}$ treatment. DT $\gamma \mathrm{E}$ induced a small but significant decrease in plasma prolactin levels, which is opposite to the effect induced by neuroleptics currently used. In addition, $\mathrm{DT} \gamma \mathrm{E}$ stimulated melatonin secretion in man, decreased platelet monoamine oxidase activity and reduced the secondary facilitation of the H-reflex recovery curve (for references see Van Ree et al., 1986). These effects are similar to those induced by neuroleptics. The outcome of an EEG study, showing a shift of the alpha activity to higher frequencies by DT $\gamma \mathrm{E}$ (Wieneke et al., 1985), is in line with the suggestion that the effects of $\mathrm{DT} \gamma \mathrm{E}$ in humans resemble in some respects those of conventional neuroleptic drugs.

Post mortem studies have revealed that the level of $\beta$-endorphin in hypothalamic tissue was unaltered compared to that of control subjects, but that the levels of $\alpha$ - and $\gamma$-endorphin were increased (Wiegant et al., 1988). In addition, an increased formation of $\gamma$-type endorphins upon incubation with $\beta$-endorphin in vitro has been found for preparations from post mortem brains of schizophrenic patients (Schoemaker and Davis, 1984). This increased formation may be related to the disease of the patients or may have been induced 
by chronic neuroleptic treatment before autopsy. In rats, chronic treatment with neuroleptics leads to changes in the $\beta$-endorphin- $\gamma$-endorphin homeostasis (Davis et al., 1984; Sweep et al., 1990). Interestingly, the $\gamma$-endorphin isolated from brain tissues of schizophrenics appeared to have a deviant action in a specific bioassay for $\gamma$-type endorphin action (De Wied, 1987). This suggests that a functional deficiency of $\gamma$-type endorphin may indeed be present in the brains of schizophrenics, which accords with the $\gamma$-type endorphin hypothesis of the disease.

The results obtained so far support the hypothesis that disturbances in central peptidergic systems, i.e., the fragmentation of $\beta$-endorphin, may be implicated in the pathogenesis of schizophrenic psychoses. Subject characteristics, such as the degree of intensity of negative psychotic symptoms and the presence of certain HLA antigens, may be involved in the responsiveness of the patients to treatment with $\gamma$-type endorphins. Further studies should therefore be focused on the delineation of patients particularly sensitive to peptide treatment using both clinical and biochemical parameters.

\section{Other peptides}

\section{Schizophrenia}

Besides $\gamma$-type endorphins, other peptides have been implicated in schizophrenia. Most investigators so far have concentrated on the opioid peptides (the endorphins) and peptides related to the hormone cholecystokinin.

\section{Opioid peptides}

With respect to endorphins two lines of research were followed, i.e., endorphin excess and endorphin deficiency.

The endorphin excess hypothesis is based on the initial observation of Terenius and co-workers that the concentration of an endorphin-like material, especially of fraction I, was increased in the cerebrospinal fluid (CSF) of a number of acute schizophrenic patients, while only a few chronic schizophrenics had an enhanced level. Treatment with neuroleptics significantly lowered the fraction I level, while no consistent trends in fraction II levels were observed (Terenius et al., 1976; Rimón et al., 1980). Subsequent studies revealed that fraction I contains among others dynorphin and fraction II enkephalins (Nyberg et al., 1983). Supporting evidence for this hypothesis 
came from animal experiments showing that $\beta$-endorphin caused a naloxonereversible postural rigidity which was interpreted to be reminiscent of the catatonic posturing sometimes observed in schizophrenic patients (Bloom et al., 1976). Concerning the $\beta$-endorphin levels in blood and CSF no consistent findings have been reported, in that both increased and decreased levels were found in patients with schizophrenic psychoses when compared with normal subjects.

If an excess of endorphin activity contributes to psychotic symptomatology, then opioid receptor blockade should cause improvement. Initially, Gunne et al. (1977) reported a transient reduction of psychotic symptoms, in particular auditory hallucinations, in four out of six chronic schizophrenic patients after a single intravenous injection with a low dose of naloxone. Subsequently, a number of clinical studies have been performed following open, single- or double-blind designs in which schizophrenic patients were treated with a single injection of naloxone i.v. (0.4-25 mg) or s.c. $(20 \mathrm{mg})$ or received oral treatment with naltrexone ( $50-800 \mathrm{mg}$ daily) for 9 days to 8 weeks. In about one fourth of the patients a temporary reduction of auditory hallucinations was observed associated with a decrease of paranoid-suspiciousness symptoms. Interestingly, these effects were observed particularly in patients concurrently treated with neuroleptics (Verhoeven et al., 1981a; Pickar et al., 1982). A limited number of schizophrenic patients have been treated so far with repeated injections of naloxone without clinically apparent therapeutic efficacy (Verhoeven et al., 1984a; Pickar et al., 1989). In an open study, however, marked beneficial effects were found of high doses of naloxone administration over 3-21 days (cumulated amount up to $380 \mathrm{mg}$ ) in patients with schizophrenic stupor (Schenk et al., 1978). Thus, there is circumstantial evidence that blockade of opioid receptors following single administration of opiate antagonists is associated with a transient reduction of psychotic symptomatology in a naloxonesensitive subgroup of schizophrenic patients.

Another way to decrease opioid activity in the body is to remove the endorphins by hemodialysis. The first report of this came from Feer et al. (1960) who described that three out of five schizophrenic patients improved after only one or two haemodialyses. Wagemaker and Cade (1977) reported a dramatic improvement in a small number of schizophrenic patients who were treated with weekly dialysis for up to 16 weeks. It was proposed that this procedure eliminates from the blood an abnormal endorphin or other substances sustaining the illness. Subsequently, it was found that the first dialysate of four schizophrenic patients contained a high level of $\left[\mathrm{Leu}^{5}\right] \beta$-endorphin, a relative of $\beta$-endorphin in which methionine at position 5 is 
replaced by leucine (Palmour et al., 1978). However, others could not confirm this finding of enhanced levels of $\left(\mathrm{Leu}^{5}\right)-\beta$-endorphin in blood or dialysates of schizophrenic patients. So far, at least 250 schizophrenic patients have been dialysed using open and double-blind designs (for references see: Van Ree and De Wied, 1981). Although about one third of the patients improved more or less upon hemodialysis in the open studies, this beneficial effect could not be replicated under double-blind conditions. Thus, even if hemodialysis may be useful for treating certain schizophrenic patients, the background for its possible beneficial effect is as yet unknown.

The endorphin deficiency hypothesis was based on observations in animal experiments that injection of $\beta$-endorphin into the periaqueductal gray matter of the brain stem of rats induces a postural rigidity which was interpreted as similar to the symptoms of catalepsy induced by neuroleptics (Jacquet and Marks, 1976). In addition, beneficial effects on schizophrenic syndromes have been reported after administration of morphine (Carlson and Simpson, 1963). Consequently, the hypothesis was formulated that $\beta$-endorphin may be an endogenous antipsychotic substance and clinical studies were performed subsequently with $\beta$-endorphin and the synthetic met-enkephalin analogue FK 33-824.

Kline and coworkers were the first to report that intravenous injection of $\beta$-endorphin to four chronic schizophrenic patients, using an open design, after an initial worsening of cognitive difficulties associated with increased difficulty in conceptualizing and mood elevation, induced a long-lasting and progressive reduction of psychotic symptoms (Kline et al., 1977). Subsequently, four double-blind studies were performed in which a total of 29 patients received i.v. $\beta$-endorphin (see Van Ree and De Wied, 1981). In only four patients was a temporary reduction of psychotic symptoms lasting some days observed. Thus, although $\beta$-endorphin may, after an initial tendency to worsen, have some beneficial effects in a small number of schizophrenic patients, the results obtained so far are not impressive. In view of the reported beneficial after-effects, it might be of interest to study the influence of (sub)chronic treatment with $\beta$-endorphin.

The potent opioid peptide FK 33-824 shares many of the biological properties of $\beta$-endorphin (Roemer et al., 1977) and has been used in three studies involving a total of 17 schizophrenic patients (see Van Ree and De Wied, 1981). Nine patients improved upon treatment, in that psychotic symptoms decreased for several hours to days. The peptide induced some morphine-like side effects shortly after the injection.

In conclusion, the data collected so far with $\beta$-endorphin are inconclusive 
and do not support the hypothesis that an endorphin deficiency may be a cause underlying schizophrenia. The beneficial effects as reported with FK 33-824 could, at least partly, be due to the morphine-like effects of this peptide.

\section{CCK-related peptides}

Peptides related to cholecystokinin (CCK) have been demonstrated in the brain where its predominant form is the C-terminal octapeptide (CCK-8); this has been shown to co-exist with dopamine in neurons of the mesencephalon which project to the limbic system, including the nucleus accumbens (Hökfelt et al., 1980). These data, together with the observations that CCK fragments inhibit the dopamine release in dopaminergic neurons of mesolimbic structures and that CCK-related peptides induce neuroleptic-like effects in experimental animals, led to the hypothesis that these neuropeptides may be involved in schizophrenia (for references see Van Ree et al., 1983). Subsequently, the influence of these neuropeptides, including ceruletide, on rat behavior was investigated using tests predicting antipsychotic activity. It appeared that the spectrum of activities of CCK-8-related peptides closely resembles that of antipsychotic agents, including $\gamma$-type endorphins (Van Ree et al., 1983).

Moroji et al. (1982) reported that ceruletide - a peptide related to CCK-8 induced antipsychotic effects in 16 out of 20 chronic schizophrenic patients after one i.m. injection. Several studies were performed subsequently, reporting conflicting results when CCK-like peptides were administered to schizophrenic patients (Nair et al., 1986). Recently, Itoh et al. (1986) reported the results of a large double-blind placebo-controlled study including 265 patients. Ceruletide in a dose of $0.6-0.8 \mu \mathrm{g} / \mathrm{kg}$ intramuscularly was given four times during 4 consecutive weeks, while 130 patients received placebo injections only. No differences were observed between the ceruletide- and placebo-treated patient groups with respect to reduction of psychotic symptomatology. In another study, Yamagami et al. (1986) investigated the dose regimen of ceruletide by an intrapatient titrated dose of $0.6-2.0 \mu \mathrm{g} / \mathrm{kg}$ body weight, given once weekly for 8 weeks in addition to conventional neuroleptic treatment, in 21 chronic schizophrenics who showed no response or only partial response to neuroleptic medication. Of the 21 patients, nine improved, one worsened and 11 did not change in their psychotic symptomatology. It appeared that the optimal dose of ceruletide, in both efficacy and safety, ranged from 1.0 to 1.2 $\mu \mathrm{g} / \mathrm{kg}$ body weight. From this study it was concluded that the inconsistency in 
the efficacy of ceruletide in the treatment of schizophrenia may be due to the dose regimens used in the different studies.

In order to investigate the possible differential effects between $\mathrm{DE} \gamma \mathrm{E}$ and ceruletide, we performed a double-blind placebo-controlled study including a total of 44 patients (Verhoeven et al., 1986b, see Table 1). Diagnostic procedures, assessment of psychotic symptoms and clinical effects were similar to those as described for the $\gamma$-type endorphin studies. The experimental period started with one placebo injection for all patients. One week later subjects received a single i.m. injection of $40 \mu \mathrm{g}$ ceruletide, $3 \mathrm{mg} \mathrm{DE} \gamma \mathrm{E}$ or placebo. After an interval of 10 days, patients received injections of identical treatment but on this occasion three times weekly for 2 weeks. This study revealed a clinically relevant improvement in 14 patients (DE $\gamma E$ : $n=6$; ceruletide: $\mathrm{n}=8$ ), while in the other 16 subjects a slight or no antipsychotic effect was observed (DE $\gamma E: n=9$; ceruletide: $n=7$ ). In three of the 14 patients treated with placebo only, a slight reduction of psychotic symptoms was observed, but in none was a clinically relevant improvement found. With respect to the effects of $\mathrm{DE} \gamma \mathrm{E}$ or ceruletide on symptoms included in the BPRS scales, no differences could be demonstrated between the two peptides. As mentioned previously, a greater intensity of negative psychotic symptoms, as assessed with the baseline BPRS scores, negatively influenced the response to $\gamma$-type endorphins. Interestingly, this study revealed similar data not only for DE $\gamma E$ but also for ceruletide. With respect to the baseline PSE syndrome profiles, however, no significant differences could be demonstrated between patients who responded $<50 \%$ (DE $\gamma E+$ ceruletide: $n=14$ ) and those with a response of $<50 \%$ (DE $\gamma \mathrm{E}+$ ceruletide: $\mathrm{n}=16$ ). That significant differences, as observed previously in the $\gamma$-type endorphin studies, were not found in this trial is most probably due to the selection of the subjects as patients diagnosed as "residual" or "catatonic" type were excluded. These data demonstrate that the neuroleptic-like neuropeptides $\gamma$-type endorphins (i.e. DE $\gamma E$ ) and ceruletide are similarly effective in decreasing psychotic symptomatology of schizophrenic patients. In addition they support the assumption that patients showing predominantly negative symptoms are less likely to respond to treatment with these kinds of peptide.

\section{Affective disorders}

Neuropeptides have not been studied extensively in animal models used to search for potential antidepressant entities. One of these models is brain stimulation reward, which may bear some relation with mood in humans 
(Willner, 1984). Increased sensitivity to brain stimulation reward is induced by oxytocin and its C-terminal tripeptide prolyl-leucyl-glycinamide (PLG), $\alpha$-endorphin and some ACTH neuropeptides, including the ACTH-(4-9) analogue Org 2766 (Van Ree and De Wied, 1983). The opioid peptides may be physiologically involved in brain stimulation reward, as opioid antagonists decrease sensitivity to this reward during and after chronic treatment (Van Wolfswinkel et al., 1985). In a learned immobility test, a widely used animal model in this respect, thyrotropin-releasing hormone (TRH) has been found to mimic the action of antidepressants (Ogawa et al., 1984). Readjustment of a normal circadian cycle after disruption of the light-dark cycle is facilitated by some antidepressants and by the peptides DGAVP and ORG 2766. In some other tests similar actions of neuropeptides and antidepressants have been found. Short-term (7 days) social isolation of rats increases social activities in a dyadic encounter test, and this increase is prevented by treatment with some antidepressants and the neuropeptides PLG, TRH and Org 2766 (Niesink and Van Ree, 1982, 1984b). The behavioral changes induced by injection of melatonin into the nucleus accumbens are antagonized by local pretreatment with some antidepressants, serotonin and the peptide $\beta$-endorphin-(10-16) (Gaffori and Van Ree, 1985a,b).

In depressed patients most studies with neuropeptides have used the tripeptide TRH (Prange et al., 1987). The peptide appeared to be ineffective in most double-blind studies using oral administration. However, after intravenous administration, a short-lasting antidepressant effect has been observed in about half of the studies, which include more than 500 patients. An improvement of clinical significance has been found in only a limited number of patients. The C-terminal fragment of oxytocin, the tripeptide PLG, was reported to exert an antidepressant effect in three out of four studies. Interestingly, in these studies the peptide was given orally. The antidepressant effect of PLG occurred fairly rapidly and was long-lasting and the peptide fails less often than imipramine. DDAVP given intranasally to a limited number of depressed patients improves cognition while in some an antidepressant effect has been observed as well. Whether the mood-increasing effect of DDAVP is secondary to the improvement of cognition remains to be elucidated. It has been postulated that a functional lack of endogenous opioids may be related to the pathogenesis of depressed symptomatology. This postulate has led to some trials in which the opioid $\beta$-endorphin or an enkephalin analogue was administered. A positive effect of $\beta$-endorphin has been found in one out of three double-blind studies. The enkephalin analogue FK 33-824 induced a short-lasting antidepressant effect in about half of the patients. 
There have been some reports that the opioid antagonist naloxone may worsen the condition of depressed patients. In addition, a beneficial effect of naloxone in manic patients has been reported. The opioid fragment of $\beta$-endorphin, des-Tyr ${ }^{1}-\gamma$-endorphin (DT $\gamma E$ ) which exerts antipsychotic action in a number of schizophrenic patients, has also been given to depressed patients. It has been reported that DT $\gamma \mathrm{E}$ treatment resulted in a antidepressant effect on some patients (Chazot et al., 1985).

In conclusion, several peptides have been studied in affective disorders. However, except for TRH, there have only been a limited number of trials with the various peptides. Nevertheless, some promising leads are available, e.g., the antidepressant effect of PLG, and it will be worthwhile to pursue them further.

\section{Addiction}

The presence of endorphins in pituitary and brain has raised the question whether these entities are involved in the functioning of neuronal substrates affected by addictive drugs. The endorphins may mediate or modulate the reinforcing effects of opiates and other addiction drugs, which may underlie drug-taking behavior. $\beta$-Endorphin supports self-administration when administered intracerebroventricularly (Van Ree et al., 1979). Also, the shorter endorphins, the enkephalins and enkephalin analogues have been shown to serve as reinforcers in naive and opiate-dependent animals. Thus, endorphins and especially $\beta$-endorphin have intrinsic reinforcing properties. Opiates may mimic these properties and in this way organisms may become dependent on these drugs. It has been postulated that endorphins and particularly $\beta$-endorphin may be a critical endogenous factor in addiction behavior in general. Blockade of opiate receptor systems with opioid antagonists decreased the ethanol intake of monkeys (Kornet et al., 1987) and under certain conditions attenuated acquisition of cocaine self-administration in rats (De Vry et al., 1989). Self-administration of both heroin and cocaine in rats is accompanied by a decrease of $\beta$-endorphin levels in the anterior part of the brain limbic system (Sweep et al., 1989). Thus $\beta$-endorphin and the other endorphins may be common factors in the addiction to various psychoactive drugs and habits, like gambling and jogging (Van Ree, 1987). It should, however, be kept in mind that multiple reward systems may be present in the brain in which endorphins may be implicated and in which endorphins are not primarily involved. It seems worthwhile, however, to study the involvement of endorphins in human addiction behavior in detail. 


\section{Concluding remarks and perspectives}

The number of studies with ACTH-like peptides which report positive effects in the realm of cognitive functions is fairly limited. It appears that the patient groups of interest are those suffering from mild (not moderate or severe) deficits, and that the length of the treatment period should be enlarged to at least several weeks to permit the build-up of a reliable treatment effect. Of interest are the effects of ACTH neuropeptides in patients with disturbances in social behavior (elderly, autism). The beneficial effects seen with Org 2766 in these patients are in line with animal studies in this respect but should be studied in more detail. Also the influence of these peptides on the regeneration process after brain damage may be of importance for the clinic. It seems worthwhile to continue studies in which elderly patients with an early phase dementia are treated with Org 2766 or related peptides and to evaluate the mood changes, social behavior and the course of the disease that is normally progressive in nature.

The human studies performed with vasopressin neuropeptides appear to prove that these peptides do have behavioral effects in humans. This conclusion is based upon the fact that most studies find something, be it a clinical impression of improvement or objective test results. Many studies in which the peptides were ineffective were performed on patients with a complex pattern of neuropsychological deficits or other symptoms of profound brain degeneration. This should not be surprising, because degeneration of the relevant brain structures may well destroy the sites of action of the peptide. More positive effects have been found in mild trauma patients compared to severe subjects. The same is true for the alcoholic/Korsakoff patients and early versus late stages in senile dementia. Interestingly, the majority of studies in volunteers have reported a positive effect of the treatment. Taken together, this may indicate that future studies should focus on those patients who have mild deficits without pronounced anatomical destruction. The subjects of choice for vasopressin studies are patients with after-effects of brain concussion, elderly people with mild senescent forgetfulness, very early dementia, and depression. The patient groups should be more defined neuropsychologically, to assess specific influences on types or aspects of memory. We suggest that information-processing tasks which measure the processes underlying both consolidation and retrieval and other aspects of memory may be the most relevant factors to study. Better and more specific methods of treatment evaluation (including parallel test versions) should be used. Another comment concerns the nature and amount of the active principle. The amount of vasopressin that 
can be used in humans is limited, due to peripheral side effects, while high doses are necessary to enable sufficient vasopressin to pass the blood-brain barrier and reach the central nervous system. Vasopressin congeners that are resistant to metabolic degradation would therefore be of value. DGAVP is favored over DDAVP, and especially LVP, because it lacks the peripheral endocrine effects which occur with AVP /LVP and partly with DDAVP. In the near future, peptides like $\left(\mathrm{pGlu}^{4}, \mathrm{Cyt}^{6}\right) \mathrm{AVP}-(4-8)$, that are generated from vasopressin by brain enzyme systems, may be used (Burbach et al., 1983). Furthermore, it may be necessary to treat for relatively prolonged periods of time (weeks) to enable a relevant treatment effect to develop.

It has become obvious that $\gamma$-type endorphins possess antipsychotic properties in a subgroup of patients whose main characteristics appear to be a relatively short duration of the last psychotic episode, previous treatment with relatively low doses of neuroleptics and a relatively low intensity of negative psychotic symptoms, suggesting that these patients may have type I schizophrenia (Crow, 1982). In addition, patients responding to $\gamma$-type endorphin treatment may be genetically different from the non-responders, as has been concluded from studies concerning antigens of the HLA system. Typing patients for these antigens may have predictive value for their responsiveness to treatment with $\gamma$-type endorphins. Concerning the studies with CCK-related peptides, the results obtained so far suggest an antipsychotic efficacy in some patients that is more or less comparable to that of $\gamma$-type endorphins, especially in patients who do not present with a high intensity of negative psychotic symptoms. Although a transient beneficial effect on psychotic symptomatology has been found with opioid antagonists, the role of endogenous opioids in schizophrenia is uncertain. It has to be emphasized that the interpretation of the clinical data concerning neuropeptides and schizophrenia should be done carefully since most of the trials were conducted on limited patient populations and not all studies used a placebo-controlled design.

Some leads are available suggesting that certain neuropeptides may be used as therapeutic agents in affective disorders. Treatment with PLG and TRH alleviates symptomatology in some depressed patients. Certain neuropeptides can mimic the action of antidepressants in animals and are effective in animal models of affective disorders. However, more detailed animal and human research in this field is needed before definite conclusions can be drawn.

In general, the results with neuropeptides in the clinic have so far been less impressive than those observed in the laboratory. This may be due to the bioavailability of the peptide in the brain after peripheral administration. Thus, methods to increase this bioavailability may improve effective treat- 
ment. Neuropeptides may have dual or U-shaped effects and may elicit different responses following acute and chronic administration. This makes it difficult to select the optimal treatment conditions. Knowledge of the neuropeptide receptor interaction may eventually lead to the synthesis of more rigid ligands, which may be more effective than the original endogenous ligands.

\section{References}

Ang, V.T.Y. and J.S. Jenkins, 1982, Blood CSF barrier to arginine-vasopressin, desmopressin and desglycinamide arginine-vasopressin in the dog, J. Endocrinol. 93, 319.

Applezweig, M.H. and F.D. Baudry, 1955, The pituitary-adrenocortical system in avoidance learning, Psychol. Rep. 1, 417.

Azorin, J.M., J. Charbaut, F. Granier, J.P. Huber, J.Y. Metzger, H. Richou, P. van Amerongen, A. Blum and H. Dufour, 1986, Des-enkephalin-gamma-endorphin in exacerbation of chronic schizophrenia: a double-blind, placebo-controlled study, Symposium on Neuropeptides and Brain Function, May 28-30, Utrecht, Abstracts, P52.

Beckwith, B.E. and C.A. Sandman, 1982, Central nervous system and peripheral effects of ACTH, MSH and related neuropeptides, Peptides 3, 411.

Beckwith, B.E., D.I. Couk and T.S. Till, 1983, Vasopressin analog influences the performance of males, Peptides 4, 707.

Beckwith, B.E., R.E. Til and V. Schneider, 1984, Vasopressin analog (DDAVP) improves memory in human males, Peptides 5, 819.

Bloom, F., D. Segal, N. Ling and R. Guillemin, 1976, Endorphins: profound behavioral effects in rats suggest new etiological factors in mental illness, Science 194, 630.

Born, J., H.L. Fehm and K.H. Voigt, 1986, ACTH and attention in humans: A review, Neuropsychobiology 15, 165.

Buitelaar, J.K., H. Van Engeland, J.M. Van Ree and D. De Wied, 1990, Behavioural effects of the adrenocorticotrophic hormone (4-9) analog Org 2766 in 14 outpatient autistic children, J. Autism Dev. Disord. (in press).

Burbach, J.P.H., G.L. Kovacs, D. De Wied, J.W. Van Nispen and H.M. Greven, 1983, A major metabolite of arginine vasopressin in the brain is a highly potent neuropeptide, Science 221, 1310 .

Carlson, E.T. and M.M. Simpson, 1963, Opium as a tranquillizer, Am. J. Psychiatry $120,112$.

Chazot, G., B. Claustrat, J. Brun and M. Olivier, 1985, Rapid antidepressant activity of des-tyr-gamma-endorphin: correlation with urinary melatonin, Biol. Psychiatry 20, 1026.

Claas, F.H..J., W. Verduyn, M. Mommaas-Kienhuis, W.M.A. Verhoeven, J.M. Van Ree and J.J. Van Rood, 1988, Endorphin receptors and HLA class I molecules, in: $\mathrm{MHC}+\mathrm{X}$, Complex Formation and Antibody Induction, ed. P. Iranyl (Springer Verlag, Heidelberg) p. 214.

Crow, T.J., 1982, Two syndromes in schizophrenia? Trends Neurosci. 5, 351. 
Dantzer, R., R.M. Bluthe, G.F. Koob and M. Le Moal, 1987, Modulation of social memory in male rats by neurohypophyseal peptides, Psychopharmacology 91, 363.

Davis, T.P., H. Schoemaker and A.J. Culling, 1984, Centrally acting drugs alter in vitro $\beta$-endorphin processing in the rat, Eur. J. Pharmacol. 100, 249.

De Jongh, B.M., W.M.A. Verhoeven, J.M. Van Ree, D. De Wied and J.J. Van Rood, 1982, HLA, and the response to treatment with $\gamma$-type endorphins in schizophrenia, J. Immunogen. 9, 381.

Delwaide, P.J., J.M. Devoitille and M. Ylieff, 1980, Acute effects of drugs upon memory of patients with senile dementia, Acta Psychiatr. Belg. 80, 748.

De Vry, J., I. Donselaar and J.M. Van Ree, 1988, Effects of desglycinamide ${ }^{9}$, $\left(\mathrm{ARG}^{8}\right.$ )vasopressin and vasopressin antiserum on the acquisition of intravenous cocaine self-administration in the rat, Life Sci. 42, 2709.

De Vry, J., I. Donselaar and J.M. Van Ree, 1989, Food deprivation and acquisition of intravenous cocaine self-administration in rats: effect of naltrexone and haloperidol, J. Pharmacol. Exp. Ther. 251 (in press).

De Wied, D., 1964, Influence of anterior pituitary on avoidance learning and escape behaviour, Am. J. Physiol. 207, 255.

De Wied, D., 1965, The influence of the posterior and intermediate lobe of the pituitary and pituitary peptides on the maintenance of a conditioned avoidance response in rats, Int. J. Neuropharmacol. 4, 157.

De Wied, D., 1969, Effects of peptide hormones on behavior, in: Frontiers in Neuroendocrinology, eds. W.F. Ganong and L. Martini (Oxford University Press, London) p. 97.

De Wied, D., 1978, Psychopathology as a neuropeptide dysfunction, in: Characteristics and Function of Opioids, eds. J.M. Van Ree and L. Terenius (Elsevier/NorthHolland Biomedical Press, Amsterdam) p. 113.

De Wied, D., 1984, Neurohypophyseal hormone influences on learning and memory processes, in: Neurobiology of Learning and Memory, eds. G. Lynch, J.L. McGaugh and N.M. Weinberger (Guildford Press, New York) p. 289.

De Wied, D., 1987, The neuropeptide concept, Progr. Brain Res. 72, 93.

De Wied, D. and J. Jolles, 1982, Neuropeptides derived from pro-opiocortin: behavioral, physiological and neurochemical effects, Physiol. Rev. 62, 976.

De Wied, D., G.L. Kovács, B. Bohus, J.M. Van Ree and H.M. Greven, 1978, Neuroleptic activity of the neuropeptide $\beta$-LPH $62-77$ ((des-Tyr $\left.{ }^{1}\right)-\gamma$-endorphin; DT $\gamma$ E), Eur. J. Pharmacol. 49, 427.

De Wied, D., J.M. Van Ree and H.M. Greven, 1980, Neuroleptic-like activity of peptides related to (des-tyr ${ }^{1}$ )- $\gamma$-endorphin: structure activity studies, Life Sci. 26 , 1575.

Dorsa, D.M. and J.M. Van Ree, 1979, Modulation of substantia nigra self stimulation by neuropeptides related to neurohypophyseal hormones, Brain Res. 172, 367.

Durso, R., P. Fedio, P. Brouwers, C. Cox, A. Martin, S.A. Ruggieri, C.A. Tamminga and T.N. Chase, 1982, Lysine vasopressin in Alzheimer's disease, Neurology 32, 674.

Eisenberg, J., S. Chazan-Golgorsky, J. Hatlab and R.H. Belmaker, 1985, A controlled trial of vasopressin treatment of childhood learning disorder, Biol. Psychiatry 19, 1137.

Feer, H., H. Thoelen, M.A. Massini and H. Staub, 1960, Hemodialysis in schizophrenia, Compr. Psychiatry 1, 338. 
Fehm-Wolfsdorf, G., J. Born, Th. Elbert and K.-H. Voigt, 1985, Vasopressin does not enhance memory processes: a study in human twins, Peptides 6, 297.

Fekete, M. and D. De Wied, 1982, Dose-related facilitation and inhibition of passive avoidance behaviour by the ACTH-(4-9) analog (ORG 2766), Pharmacol. Biochem. Behav. 17, 177.

Fekete, M., J.M. Van Ree and D. De Wied, 1986, The ACTH-(4-9) analog ORG 2766 and desglycinamide ${ }^{9}-\left(\mathrm{Arg}^{8}\right)$-vasopressin reverse the retrograde amnesia induced by disrupting circadian rhythms in rats, Peptides 7, 563.

Ferris, S.H., 1983, Neuropeptides in the treatment of Alzheimer's disease, in: Alzheimer's Disease, ed. B. Reisberg (Free Press/MacMillan, New York) p. 369.

Ferris, S.H., B. Reisberg and S. Gershon, 1980, Neuropeptide modulation of cognition and memory in human, in: Aging in the 1980's: Selected Contemporary Issues in the Psychology of Aging, ed. L. Poom (American Psychological Association, Washington) p. 212.

Fewtrell, W.D., A.O. House, P.F. Jamie, M.R. Oates and J.E. Cooper, 1982, Effects of vasopressin on memory and new learning in brain-injured population, Psychol. Med. 12, 423 .

File, S.E., 1981, Contrasting effects of ORG 2766 and $\alpha-\mathrm{MSH}$ on social and exploratory behaviour in the rat, Peptides 2, 255.

Fraenkel, H.M., G. Van Beek-Verbeek, A.J. Fabriek and J.M. Van Ree, 1983, Desglycinamide $^{9}$-arginine ${ }^{8}$-vasopressin and ambulant methadone-detoxification of heroin addicts, Alcohol Alcoholism 18, 331.

Frederiksen, S.O., G. d'Elia and B.O. Bengtsson, 1985, ACTH 4-9 analogue (Org 2766) in depressed elderly patients. I. Effect on depressed mood, Acta Psychiatr. Scand. 72,341 .

Gaffori, O. and J.M. Van Ree, 1985a, Serotonin and antidepressant drugs antagonize melatonin-induced behavioural changes after injection into the nucleus accumbens of rats, Neuropharmacology 24, 237.

Gaffori, O. and J.M. Van Ree, 1985b, $\beta$-Endorphin-(10-16) antagonizes behavioral responses elicited by melatonin following injection into the nucleus accumbens of rats, Life Sci. 37, 357.

Gaillard, A.W.K., 1981, ACTH analogs and human performance, in: Endogenous Peptides and Learning Memory Processes, eds. J.L. Martinez, R.A. Jensen, R.B. Messing, H. Rigter and J.L. McGaugh (Academic Press, New York) p. 181.

Greven, H.M. and D. De Wied, 1973, The influence of peptides derived from corticotropin (ACTH) on performance. Structure activity studies, Progr. Brain Res. $39,429$.

Gunne, L.M., L. Lindström and L. Terenius, 1977, Naloxone-induced reversal of schizophrenic hallucinations, J. Neural Transm. 40, 13.

Hökfelt, R., J.F. Rehfeld, L. Skirboll, B. Ivemark, M. Goldstein and K. Markey, 1980, Evidence for coexistence of dopamine and CCK in mesolimbic neurons, Nature 285, 476.

Itoh, H., Y. Shimazone, Y. Kawakita, Y. Kudo, Y. Satoh and R. Takahashi, 1986, Clinical evaluation of ceruletide in schizophrenia: a multi-institutional cooperative double-blind controlled study, Psychopharmacol. Bull. 12, 123.

Jacquet, Y.F. and N. Marks, 1976, The C-fragment of $\beta$-lipotropin: an endogenous neuroleptic or antipsychotogen?, Science 194, 632. 
Jenkins, J.S., H.M. Mather, A.K. Coughlan and D.G. Jenkins, 1981, Desmopressin and

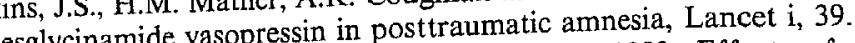

Jenkins, J.S., H.M. Mather and A.K. Coughlan, 1982, Effects of desmopressin in . Psychiatry 45, 830.

Jennekenschinkel, A., A.R. Wintzen and J.B.K. Lanser, 1985, A clinical trial with desglycinamide arginine vasopressin for the treatment of memory disorders in man, Prog. Neuropsychopharmacol. Biol. Psychiatry 9, 273.

Pres, J. 1983, Vasopressin-like peptides and the treatment of memory disorders in man, in: The Neurohypophysis: Structure, Function and Control, eds. B.A. Cross and G. Leug (Elsevier, Amsterdam) p. 169.

Jolles, J., 1986, Neuropeptides and cognitive disorders, in: Psychiatric Disorders: Neurotransmitters and Neuropeptides, eds. J.M. Van Ree and J. Matthijsse (Elsevier, Amsterdam) p. 177.

(1987, Vasopressin and human behaviour, in: Vasopressin Principles and Properties, eds. D.M. Gash and G.J. Boer (Plenum Press, New York) p. 549.

Prsting W Möller, J. Cootjans, D. Roy, B. Husebö, P. Christiansen and H.H. Godt, 1986, Multicenter double-blind comparison between des-enkephalin- $\gamma$-endorphin (DE $\gamma \mathrm{E}$, Org 5878) and haloperidol concerning the efficacy and safety in the treatment of schizophrenia, in: Psychiatry and its Related Disciplines, the Next 25 Years, World Psychiatric Association, Regional Symposium, p. 178.

Kline, N.S., C.H. Li, H.E. Lehmann, A. Lajtha, E. Laskik and Th. Cooper, 1977 , $\beta$-Endorphin-induced changes in schizophrenic and depressed patients, Arch. Gen. Psychiatry $34,1111$.

Kornet, M., C. Goosen, L. Ribbens and J.M. Van Ree, 1987, Alcohol drinking in thesus monkeys: implication of opioid systems, in: New Perspectives in Pharmacological Sciences, eds. F. Drago and J.M. van Ree (Italian Pharmacological Society, Rome) p. 95.

Korsgaard, S., D.E. Casey, N.E. Damgaard Pedersen, A. Jörgensen and J. Gerlach, 1981, Vasopressin in anergic schizophrenia, Psychopharmacology 74, 379.

Kragh-Sørensen, P. and A. Lolk, 1987, Neuropeptides and dementia, Progr. Brain Res. 72,269

Láczi, F., Zs. Valkusz, F.A. Laszlo, A. Wagner, T. Jardanhazy, A. Szasz, J. Szilard and G. Telegdy, 1982, Effects of lysine-vasopressin and 1-desamino-8-D-argininevasopressin on the memory of healthy individuals and diabetes insipidus patients, Psychoneuroendocrinology 7, 195.

Láczi, F., J.M. Van Ree, A. Wagner, Zs. Valkusz, T. Jardanhazy, G.L. Kovács, G. Telegdy, J. Szilard, F.A. Laszlo and D. De Wied, 1983a, Effects of desglycinamidearginine-vasopressin (DGAVP) on memory processes in diabetes insipidus patients and in non-diabetic subjects, Acta Endocrinol. 102, 205.

Láczi, F., J.M. Van Ree, L. Balogh, A. Szasz, T. Jardanhazy, A. Wagner, L. Gaspar, Zs. Valkusz, I. Dobranovics, J. Szilard, F.A. Laszlo and D. De Wied, 1983b, Lack of effect of desglycinamide-arginine-vasopressin (DGAVP) on memory in patients with Korsakoff's syndrome, Acta Endocrinol. 104, 177.

Legros, J.J. and I. Lancranjan, 1984, Vasopressin in neuropsychiatric disorders, in: Psychoneuroendocrine Dysfunction, eds. N.S. Shah and A.G. Donald (Plenum Press, New York) p. 255. 
Legros, J.J., P. Gilot, X. Seron, J. Claessens, A. Adam, J.M. Moeglen, A. Audibert and P. Berchier, 1978, Influence of vasopressin on learning and memory, Lancet $\mathrm{i}, 41$.

Martin, J.C., B.R. Ballinger, L.L. Cockram, F.M. McPherson, R.M. Pigache and D. Tregaskis, 1983, Effect of a synthetic peptide, ORG 2766, on inpatients with severe senile dementia, Acta Psychiatr. Scand. 67, 205.

Messing, R.B. and S.B. Sparber, 1984, Does vasopressin really facilitate memory processes, Trends Pharmacol. Sci. 6, 149.

Moroji, T., N. Watanabe, N. Aoki and S. Itoh, 1982, Antipsychotic effects of caeruletide (caerulein) on chronic schizophrenic subjects, Psychopharmacol. Bull. 19, 134.

Nair, P.V., S. Lal and D.M. Bloom, 1986, Cholecystokinin and schizophrenia, Progr. Brain Res. 65, 237.

Nebes, R.D., C.F. Reynolds III and L.C. Horn, 1984, The effect of vasopressin on memory in the healthy elderly, Psychiatr. Res. 11, 49.

Niesink, R.J.M. and J.M. Van Ree, 1982, Antidepressant drugs normalize the increased social behaviour of pairs of male rats induced by short term isolation, Neuropharmacology 21, 1343.

Niesink, R.J.M. and J.M. Van Ree, 1983, Normalizing effect of the ACTH(4-9) analog ORG 2766 on "disturbed" social behaviour of rats; implication of endogenous opioid systems, Science 221, 960 .

Niesink, R.J.M. and J.M. Van Ree, 1984a, Analysis of the facilitatory effect of the ACTH-(4-9) analog ORG 2766 on active social contact in rats, Life Sci. 34, 961.

Niesink, R.J.M. and J.M. Van Ree, 1984b, Neuropeptides and social behaviour of rats tested in dyadic encounters, Neuropeptides 4, 483.

Nyakas, C., H.D. Veldhuis and D. De Wied, 1985, Beneficial effect of chronic treatment with ORG 2766 and $\alpha$-MSH on impaired reversal learning of rats with bilateral lesions of the parafascicular area, Brain Res. Bull. 15, 257.

Nyberg, F., A. Wahlström, B. Sjölund and L. Terenius, 1983, Characterization of electrophoretically separable endorphins in human CSF, Brain Res. 259, 267.

Ogawa, N., S. Mizuno, A. Mori, I. Nukina, Z. Ota and M. Yamamoto, 1984, Potential anti-depressive effects of thyrotropin releasing hormone (TRH) and its analogues, Peptides 5, 743.

Oliveros, J.C., M.K. Jandali, M. Timsit-Berthier, R. Remy, A. Benghezal, A. Audibert and J.M. Moeglen, 1978, Vasopressin in amnesia, Lancet i, 42.

Palmour, R.M., F.R. Erevin, H. Wagemaker and R. Cade, 1978, Characterization of a peptide from the serum of psychotic patients, in: Endorphins in Mental Health Research, eds. E. Usdin, W.E. Bunney Jr. and N.S. Kline (Macmillan and Co., New York) p. 581.

Peabody, C.A., S. Thiermann, R. Pigache, T.P. Miller, Ph.A. Berger, J. Yesavage and J.R. Tinklenberg, 1985, Desglycinamide-9-arginine-8-vasopressin (DGAVP, Org 5667) in patients with dementia, Neurobiol. Aging 6, 95.

Pickar, D., F. Vartanian, W.E. Bunney Jr., H.P. Maier, M.T. Gastpar, R. Prakash, B.B. Sethi, R. Lideman, B.S. Belyaev, M.V.A. Tsutsulkovakaja, G. Jungkunz, N. Nedopil, W. Verhoeven and H. Van Praag, 1982, Shortterm naloxone administration in schizophrenic and manic patients, Arch. Gen. Psychiatry 39, 313.

Pickar, D., W.E. Bunney Jr., P. Douillet, B.B. Sethi, M. Sharma, M.E. Vartanian, R.P. Lideman, D. Naber, K. Leibl, I. Yamashita, T. Koyama, W.M.A. Verhoeven, F. 
Vartanian, P.V. Morozov and T. Ngo Khac, 1989, Repeated naloxone administration in schizophrenia: a phase II World Health Organisation study, Biol. Psychiatry 25, 440 .

Pigache, R.M., 1982, A peptide for the aged? Basic and clinical studies, in: Psychopharmacology of Old Age, ed. D. Wheatley (Oxford University Press, Oxford) p. 67.

Pigache, R.M. and H. Rigter, 1981, Effects of peptides related to ACTH on mood and vigilance in man, in: Frontiers of Hormone Research, Vol. 8, eds. Tj.B. Van Wimersma Greidanus and L.H. Rees (Karger, Basel) p. 193.

Prange Jr., A.J., J.C. Garbutt, P.T. Loosen, G. Bissette and Ch.B. Nemeroff, 1987, The role of peptides in affective disorders: a review, Progr. Brain Res. 72, 235.

Radhakishun, F.S., B.H.C. Westerink, J.C. Stoof, G. Wolterink and J.M. Van Ree, 1990 Chronic treatment with the neuroleptic-like peptide desenkephalin- $\gamma$-endorphin may decrease dopaminergic neurotransmission in the nucleus accumbens of rats, Life Sci. (in press).

Riekkinen, P., J.-J. Legros, C. Sennef, J. Jolkkonen, S. Smitz and H. Soininen, 1987, Penetration of DGAVP (Org 5667) across the blood-brain barrier in human subjects, Peptides 8, 261.

Rimón, R., L. Terenius and R. Kampman, 1980, Cerebrospinal fluid endorphins in schizophrenia, Acta Psychiatr. Scand. 61, 395.

Roemer, D., H.H. Buescher, R.C. Hill, J. Pless, W. Bauer, F. Cardinaux, A. Closse, D, Hauser and R. Huguenin, 1977, A synthetic enkephalin analogue with prolonged parenteral and oral analgesic activity, Nature 268, 547.

Sahgal, A., 1984, A critique of the vasopressin-memory hypothesis. Psychopharmacology 83, 215.

Sandman, C.A., B.B. Walker and C.A. Lawton, 1980, An analog of MSH/ACTH 49 enhances interpersonal and environmental awareness in mentally retarded adults, Peptides 1, 109.

Schenk, G.K., P. Enders, M.P. Engelmeier, T. Ewert, S. Herdemerten, K.H. Köhler, E. Lodemann, D. Matz and J. Pach, 1978, Administration of the morphine antagonist naloxone in psychic disorders, Arzneim. Forsch. 28, 1274.

Schoemaker, H. and T.P. Davis, 1984, Differential in vitro metabolism of $\beta$ endorphin in schizophrenia, Peptides 5, 1049.

Soininen, H., T. Koskinen, E.-L. Helkala, R. Pigache and P.J. Riekkinen, 1985, Treatment of Alzheimer's disease with a synthetic ACTH 4-9 analog, Neurology 35, 1348.

Squire, L.R. and H.P. Davis, 1981, The pharmacology of memory: a neurobiological perspective, Annu. Rev. Pharmacol. Toxicol. 21, 323.

Sweep, C.G.J., V.M. Wiegant, J. De Vry and J.M. Van Ree, 1989, $\beta$-Endorphin in brain limbic structures as neurochemical correlate of psychic dependence on drugs, Life Sci. 44, 1133.

Sweep, C.G.J., C.J.C. Boersma and V.M. Wiegant, 1990, Effect of chronic haloperidol and bromoctiptine treatment on the processing of $\beta$-endorphin to $\gamma$ - and $\alpha$-endorphin in discrete regions of the rat pituitary gland and brain, Neuropharmacology (in press).

Stevens, J.R., 1979, Schizophrenia and dopamine regulation in the mesolimbic systems, Trends Neurosci. 2, 102. 
Terenius, L., A. Wahlström, L. Lindström and E. Widerlöv, 1976, Increased CSF levels of endorphins in chronic psychosis, Neurosci. Lett. 3, 157.

Timsit-Berthier, M., H. Mantanus, M.C. Jacques and J.J. Legros, 1980, Utilité de la lysine-vasopressine dans le traitement de l'amnésia post-traumatique, Acta Psychiatr. Belg. 80, 728.

Tinklenberg, J.R. and J.E. Thornton, 1983, Neuropeptides in geriatric psychopharmacology, Psychopharmacol. Bull. 19, 198.

Tinklenberg, J.R., R. Pigache, A. Pfefferbaum and P.A. Berger, 1982, Vasopressin peptides and dementia, in: Alzheimer's Disease, A Report of Progress in Research, eds. S. Corkin, K.I. Davis, J.H. Growdon, E. Usdin and R.J. Wurtman (Raven Press, New York) p. 463.

Van Beek-Verbeek, G., H.M. Fraenkel and J.M. Van Ree, 1983, Des-Gly ${ }^{9}$ [Arg $^{8}$ ]vasopressin may facilitate methadone detoxification of heroin addicts, Subst. Alcohol Action/Misuse 4, 375.

Van Ree, J.M., 1979, Reinforcing stimulus properties of drugs, Neuropharmacology 18, 963.

Van Ree, J.M., 1987, Reward and abuse: opiates and neuropeptides, in: Brain Reward Systems and Abuse, eds. J. Engel and L. Oreland (Raven Press, New York) p. 75.

Van Ree, J.M. and D. De Wied, 1977a, Modulation of heroin self-administration by neurohypophyseal principles, Eur. J. Pharmacol. 43, 199.

Van Ree, J.M. and D. De Wied, $1977 \mathrm{~b}$, Heroin self-administration is under control of vasopressin, Life Sci. 21, 315.

Van Ree, J.M. and D. De Wied, 1981, Endorphins in schizophrenia, Neuropharmacology $20,1271$.

Van Ree, J.M. and D. De Wied, 1982, Neuroleptic-like profile of $\gamma$-type endorphins as related to schizophrenia, Trends Pharmacol. Sci. 3, 358.

Van Ree, J.M. and D. De Wied, 1983, Behavioral effects of endorphins - modulation of opiate reward by neuropeptides related to pro-opiocortin and neurohypophyseal hormones, in: The Neurobiology of Opiate Reward Processes, eds. J.E. Smith and J.D. Lane (Elsevier Biomedical Press, Amsterdam) p. 109.

Van Ree, J.M. and O. Gaffori, 1983, Uniquely, $\gamma$-endorphin induces an effect that is both opiate- and neuroleptic-like, Life Sci. 33, Suppl. I, 619.

Van Ree, J.M., A. Witter and J.E. Leysen, 1978, Interaction of des-tyrosine- $\gamma$ endorphin (DT $\gamma \mathrm{E}, \beta-\mathrm{LPH}_{62-77}$ ) with neuroleptic binding sites in various areas of rat brain, Eur. J. Pharmacol. 52, 411.

Van Ree, J.M., D.G. Smyth and F. Colpaert, 1979, Dependence creating properties of lipotropin C-fragment ( $\beta$-endorphin): evidence for its internal control of behaviour, Life Sci. 24, 495.

Van Ree, J.M., H. Innemee, J.W. Louwerens, R.S. Kahn and D. De Wied, 1982a, Non-opiate $\beta$-endorphin fragments and dopamine. I. The neuroleptic-like $\gamma$-endorphin fragments interfere with behavioural effects elicited by small doses of apomorphine, Neuropharmacology 21, 1095.

Van Ree, J.M., W.M.A. Verhoeven, D. De Wied and H.M. Van Praag, 1982b, The use of the synthetic peptides $\gamma$-type endorphins in mentally ill patients, Ann. NY Acad. Sci. 398, 478.

Van Ree, J.M., O. Gaffori and D. De Wied, 1983, In rats, the behavioral profile of 
CCK-8 related peptides resembles that of antipsychotic agents, Eur. J. Pharmacol $93,63$.

Van Ree, J.M., O. Gaffori and I. Kiraly, 1984, $\gamma$-Endorphin and $\mathrm{N}^{\alpha}$-acetyl- $\gamma$ endorphin interfere with distinct dopaminergic systems in the nucleus accumbens via opioid and non-opioid mechanisms, Life Sci. 34, 1317.

Van Ree, J.M., R. Hijman, J. Jolles and D. De Wied, 1985, Vasopressin and related peptides; animal and human studies, Prog. Neuro-Psychopharmacol. Biol. Psychiatry $9,551$.

Van Ree, J.M., W.M.A. Verhoeven, F.H.J. Claas and D. De Wied, 1986, Antipsychotic action of $\gamma$-type endorphins: animal and human studies, Progr. Brain Res. 65, 221.

Van Ree, J.M., W.M.A. Verhoeven and D. De Wied, 1987, Animal and clinical research on neuropeptides and schizophrenia, Progr. Brain Res. 72, 249.

Van Ree, J.M., E.M.M. Burbach-Bloemarts and M. Wallace, 1988, Vasopressin neuropeptides and acquisition of heroin and cocaine self-administration in rats, Life Sci. 42, 1091.

Van Ree, J.M., J. Elands, I. Király and G. Wolterink, 1989, Antipsychotic substances and dopamine in the rat brain; behavioral studies reveal distinct dopamine receptor systems, Eur. J. Pharmacol. 166, 441.

Van Wimersma Greidanus, Tj.B., J.M. Van Ree and D. De Wied, 1983, Vasopressin and memory, Pharmacol. Ther. 20, 437.

Van Wolfswinkel, L., W.F. Seifert and J.M. Van Ree, 1985, Long-term changes in self-stimulation threshold by repeated morphine and naloxone treatment, Life Sci. 37,169 .

Verhaagen, J. and W.H. Gispen, 1988, Peripheral nerve regeneration, neurotrophic factors and neuropeptides, in: Recovery of Function in the Nervous System, eds. F. Cohadon and J. Lobo-Antunes (Liviana Press, Padua) p 21.

Verhoeven, W.M.A. and J.A. Den Boer, 1988, Novel atypical antipsychotic compounds; recent developments in the treatment of schizophrenia, in: Tardive Dyskinesia: Biological Mechanisms and Clinical Aspects, eds. M.E. Wolf and A.D. Mosnaim (American Psychiatric Press, Washington) p. 245.

Verhoeven, W.M.A., H.M. Van Praag, J.M. Van Ree and D. De Wied, 1979, Improvement of schizophrenic patients by treatment with (Des-Tyr)- $\gamma$-endorphin (DT $\gamma$ E), Arch. Gen. Psychiatry 36, 294.

Verhoeven, W.M.A., H.M. Van Praag and J.T.V.M. De Jong, 1981a, Use of naloxone in schizophrenic psychoses and manic syndromes, Neuropsychobiology 7, 159.

Verhoeven, W.M.A., H.G.M. Westenberg, A.W. Gerritsen, H.M. Van Praag, J.H.H. Thijssen, F. Schwarz, J.M. Van Ree and D. De Wied, 1981b, (Des-Tyrosine ${ }^{1}$ )- $\gamma$-endorphin in schizophrenia: clinical, biochemical and hormonal aspects, Psychiatr. Res. 5, 293.

Verhoeven, W.M.A., J.M. Van Ree, A. Heezius-Van Bentum, D. De Wied and H.M. Van Praag, 1982, Antipsychotic properties of (des $\{171\}$ enkephalin)- $\gamma$-endorphin (DE $\gamma \mathrm{E} ; \beta$-LPH 66-77) in schizophrenic patients, Arch. Gen. Psychiatry 39, 648.

Verhoeven, W.M.A., H.M. Van Praag and J.M. Van Ree, 1984a, Repeated naloxone administration in schizophrenia, Psychiatr. Res. 12, 297.

Verhoeven, W.M.A., J.M. Van Ree, H.G.M. Westenberg, J.M. Krul, G.J. Brouwer, J.H.H. Thijssen, D. De Wied, H.M. Van Praag, D.L.S. Ceulemans and R.S. Kahn, 
1984b, Clinical, biochemical and hormonal aspects of treatment with des-tyr ${ }^{1}-\gamma$-endorphin in schizophrenia, Psychiatr. Res. 11, 329.

Verhoeven, W.M.A., J.M. Van Ree and D. De Wied, 1986a, Neuroleptic-like peptides in schizophrenia, in: Handbook on Studies in Schizophrenia, eds. G.D. Burrows, T.R. Norman and G. Rubinstein (Elsevier, Amsterdam) p. 253.

Verhoeven, W.M.A., H.G.M. Westenberg and J.M. Van Ree, 1986b, A comparative study on the antipsychotic properties of desenkephalin- $\gamma$-endorphin and ceruletide in schizophrenic patients, Acta Psychiatr. Scand. 37, 372.

Wagemaker, H. and R. Cade, 1977, The use of hemodialysis in chronic schizophrenia, Am. J. Psychiatry 134, 684.

Weingartner, H., P. Gold, J.C. Ballenger, S.A. Smallberg, R. Summers, D.R. Rubinow, R.M. Post and F.K. Goodwin, 1981a, Effects of vasopressin on human memory functions, Science 211, 601 .

Weingartner, H., W. Kaye, P. Gold, S. Smallberg, R. Peterson, J.C. Gillin and M. Ebert, 1981b, Vasopressin treatment of cognitive dysfunction in progressive dementia, Life Sci. 29, 2721.

Wiegant, V.M., C.J. Verhoef, J.P.H. Burbach and D. De Wied, 1988, Increased concentration of $\alpha$ - and $\gamma$-endorphin in post mortem hypothalamic tissue of schizophrenic patients, Life Sci. 42, 1733.

Wieneke, G.H., F.H. Lopes da Silva, W.M.A. Verhoeven and J.M. Van Ree, 1985, The effect of Des-Tyrl- $\gamma$-endorphin (DT $\gamma E$ ) on the EEG spectrum of schizophrenic patients, New Trends Exp. Clin. Psychiatry 1, 3.

Willner, P., 1984, The validity of animal models of depression, Psychopharmacology $83,1$.

Wolterink, G., E. Van Zanten, H. Kamsteeg, F.S. Radhakishun and J.M. Van Ree, 1989, Functional recovery after destruction of dopamine systems in the nucleus accumbens of rats. II: Facilitation by the ACTH-(4-9) analog ORG 2766, Brain Res. (in press).

Yamagami, S., E. Hirayama, K. Mori and Y. Kawakita, 1986, Dose-effect relationship of ceruletide in the treatment of neuroleptic-resistant schizophrenia, Curr. Ther. Res. 39, 1044. 